Research Article

\title{
Natural Products as Sources of Antimalarial Drugs: Ethnobotanical and Ethnopharmacological Studies
}

\author{
Oluwole Solomon Oladeji (D), Abimbola Peter Oluyori, Deborah Temitope Bankole (D), \\ and Tokunbo Yemisi Afolabi
}

\begin{abstract}
Natural Products Research Unit, Department of Physical Sciences, College of Pure and Applied Sciences, Landmark University, PMB 1001, Omu Aran, Kwara State, Nigeria
\end{abstract}

Correspondence should be addressed to Oluwole Solomon Oladeji; oladeji.oluwole@lmu.edu.ng

Received 2 October 2019; Revised 6 April 2020; Accepted 24 April 2020; Published 11 May 2020

Academic Editor: David P. Horvath

Copyright (C) 2020 Oluwole Solomon Oladeji et al. This is an open access article distributed under the Creative Commons Attribution License, which permits unrestricted use, distribution, and reproduction in any medium, provided the original work is properly cited.

\begin{abstract}
Ethnopharmacological Relevance. Malaria is one of the lethal diseases of man, contributing to about 17 million deaths annually, leading to sociocultural, economic, and health influences. Aim of the Study. The study explores the ethnobotanical and ethnopharmacological appraisal of antimalarial plants used by people of Omu Aran, Ogbomoso, Ado Ekiti, and Sagamu communities in Nigeria. Materials and Methods. For this study, relevant information was procured from the inhabitants via a structured questionnaire to procure the general knowledge of antimalarial medicinal plants. Results and Discussion. A total of 90 interviewees (44 men and 46 women) were involved in this survey. A total of 59 medicinal species were identified, which were dispersed in 33 families (Asteraceae (6), Apocynaceae (5), Anacardiaceae, Annonaceae, Fabaceae, Malvaceae, Meliaceae, Poaceae, and Rubiaceae (3 each), Phyllanthaceae (2)) totaling $49 \%$ of the cited species. The most cited plants are Azadirachta indica (42), Mangifera indica (38), Carica papaya (28), Cymbopogon citratus (27), Cassia fistula (15), Morinda lucida (14), Anacardium occidentale and Vernonia amygdalina (13 each), Helianthus annuus (11), Enantia chlorantha (10), and Moringa oleifera (9) A total of 105 citations were recorded for the plant parts used (leaf (46), bark (17), fruits (9), root (9), latex (11), stem (11), and inflorescence (2)) while decoction (59\%), maceration (25\%), infusion (9\%), and exudation (7\%) were the methods of preparation. Use Values (UVs) of 0.47 to 0.11 were recorded for the frequently used antimalarial plants. The Efficiency Levels (ELs) of 11 different medicinal plants stated by the respondents were Azadirachta indica, Cassia fistula and Morinda lucida (12), Chromolaena odorata (10), Mangifera indica, Enantia chlorantha and Helianthus annuus (8), Cymbopogon citratus (7), Gossypium arboretum (4), Landolphia dulcis (3), and Aloe vera (2) Cocos nucifera, Curcuma longa, Forkia biglobosa, and Musa acuminate are mentioned for the first time in the study area with little or no reported antiplasmodial activities. Conclusion. The study appraised the commonly used antimalarial plants in the study areas. Therefore, commitment to scientifically explore the bioactive compounds, antimalarial potential and toxicological profile of these plants is inevitable as they could lead to novel natural products for effective malaria therapy.
\end{abstract}

\section{Introduction}

Malaria is one of the communal diseases of man contributing to stern sociocultural, economic, and health influences in humid, middle-income nations, sub-Saharan Africa, Southeast Asia, and South America $[1,2]$. It is instigated by Plasmodium ovale, P. malariae, P. falciparum, P. vivax, and P. knowlesi [3]. The outburst of malarial infections in Africa, the Caribbean, Asia, and South American is symptomatic of $P$. falciparum, the most lethal malaria parasite. The parasite could accumulate in the brain capillaries [4, 5]. Malarial infections in India, Central American, and East Mediterranean could be concomitant to $P$. vivax while $P$. ovale and $P$. malariae are prevalent in Papua New Guinea and subSaharan Africa [6].

Malaria epidemic has been enormously high in low socioeconomic empowered regions. In Africa, nearly 19 million cases of malaria infections have been reported accounting to $89 \%$ of the global cases and almost 17 million deaths have been published [7]. Also, about 450 thousand 
African children's deaths have been reported and one-tenth of pregnancy deaths have been concomitant to malaria infections $[2,8]$. It affected the morbidity and mortality rate owing to pathogenic resistance to conventional drugs, vector control agents, and human migration [9]. Several factors have been analysed and reported to control malaria infections in Africa. These are climate suitability, dams or reservoirs, migration, and vegetation. According to the report published by The World malaria in 2018, malarial cases have tremendously reduced in relation to the report of 2010 . Despite this, between 2015 and 2017, no significant progress was achieved in curbing malaria cases [10]. This trend could be indicative of the widely spread of drug-resistant malaria and the intricacy of parasites' life cycle [11].

Quinoline (QN) derivatives are undoubtedly the commonest antimalarial drugs in Africa. Examples of quinoline antimalarial drugs are quinine, amodiaquine, piperaquine, primaquine, pyronaridine, ferroguine, isoquine, amopyroquine, tertbutylisoquine, mefloquine, tafenoquine, and chloroquine. 4-Aminoquinoline is the most accessible antimalarial pharmacophore used in the last century. In recent times, QN derivatives have been integral component of Artemisinin-based Combination Therapy (ACT) [12]. The discovery of ACT could be considered as the most noteworthy achievement of ethnopharmacological research in the 20th century [13-15], enthused by the use of Artemisia annua L. (Asteraceae). The drug was found effective against all the malarial parasites and led to regulations against quinine-based drugs in Africa. However, despite the predominant achievements of ACT, concerns about the future efficacy of artemisinin have recently been on the rise due to the building-up of resistance by the parasite [7]. This event instigates the unrelenting search for promising antimalarial drugs that are cost-effective, handy, acceptable, and scientifically proven.

Human has used medicinal plants for malaria, cholera, yellow fever, and diabetes treatment [16]. In most African countries, medicinal herbs are viewed as alternative therapies. Medicinal plants have effectively helped in primary health care for the therapy of acute and chronic diseases $[17,18]$. They have contributed to the discovery of novel therapeutic agents via isolation, identification, and characterization of secondary metabolites [19]. Secondary metabolites such as flavonoids, stilbenes, coumarins, lignin, tannins, terpenoids, and steroids have been reported as antimalarial compounds [20].

Tropical plants are identified to contain high proportions of natural chemical compounds and a greater diversity than plants from any other biome. Thus, they are potential sources of new medicines [21]. The increased number of drug-resistant strains makes the development of novel antimalarial urgent. The high cost of malaria treatment has left the poor masses of Nigeria heavily reliant on traditional practitioners and medicinal plants for the treatment of the disease. It seems logical to encourage studies on plants from these regions, especially since the major proportions of malaria attributable deaths occur in sub-Saharan African regions. Although several compounds had achieved success at treating malaria diseases, the emerging threats of drug resistance by some plasmodium species call for the development of new molecules with novel bioactive features. The study explores the ethnobotanical and ethnopharmacological appraisal of antimalarial plants used by people of Omu Aran, Ogbomoso, Ado Ekiti, and Sagamu communities in Nigeria. Hence, the search for novel natural antimalarial molecules in selected plant sources via ethnobotanical and ethnopharmacological investigation is clearly justified.

\section{Methodology}

2.1. Geographical Description of the Study Area. The study area comprises four states, namely, Kwara (Omu Aran), Oyo (Ogbomoso), Ekiti (Ado Ekiti), and Ogun (Sagamu) in Nigeria located on $8^{\circ} 08^{\prime} \mathrm{N} \quad\left(5^{\circ} 06^{\prime} \mathrm{E}\right), 8^{\circ} 08^{\prime} \mathrm{N}\left(4^{\circ} 15^{\prime} \mathrm{E}\right)$, $7^{\circ} 37^{\prime} 16^{\prime \prime} \mathrm{N}\left(5^{\circ} 13^{\prime} 17^{\prime \prime} \mathrm{E}\right)$, and $6^{\circ} 50^{\prime} \mathrm{N}\left(3^{\circ} 39^{\prime} \mathrm{E}\right)$, respectively. The study areas are located in two important geopolitical zones, that is, Omu Aran (North central), Ogbomoso, Sagamu, and Ado Ekiti (Southwest) of Nigeria (Figure 1) The inhabitants are majorly from the Yoruba ethnic group. The study area falls into the category of state with most prevalence of malaria in Nigeria according to MIS report.

2.2. Typical Vegetation of the Study Area. Ado Ekiti and Sagamu fall in the rain forest region, characterized by temperature of $21^{\circ}$ to $28^{\circ} \mathrm{C}$, high humidity, and two distinct seasons, rainy season from April to October and dry season from November to March with mean annual rainfall of $1320 \mathrm{~mm}$. Ogbomoso and Omu Aran fall in the savanna region, characterized by temperature of $21^{\circ}$ to $33^{\circ} \mathrm{C}$ with heavy rainfall between April and October. The humidity is high $(51.1 \%)$ with mean annual rainfall of $1885 \mathrm{~mm}$. The study sites are opulently rich in evergreen floras and this promotes the use of local herbs for diseases prevention and cure.

2.3. Selection of the Informants. For this study, relevant information and data were procured from selected people in the study area via interview using structured questionnaire to procure relevant knowledge of antimalarial plants used in the vicinity. The questions were structured in a simple way and interpreted to selected respondents selected by nomination method after verbal authorization and approval by the chiefs in the study areas. In a particular study area, the leaders suggested prominent people with vast experience in herbal medicines or practitioners of herbal medicines. For reliability and reproducibility, respondents that accepted to be interviewed were briefed on the significance and objectives of the study. A disclaimer was presented to the interviewees that the views, ideas, and opinions expressed belong solely to the interviewers, and not necessarily to any committee or individual. While conducting the research, researchers were honest but not too detailed in briefing the respondents what he or she needed to do. Conducting the survey involved series of activities. These include establishing cordial relationship with respondents, selecting easy ways of interacting, observation, and recording the findings. 


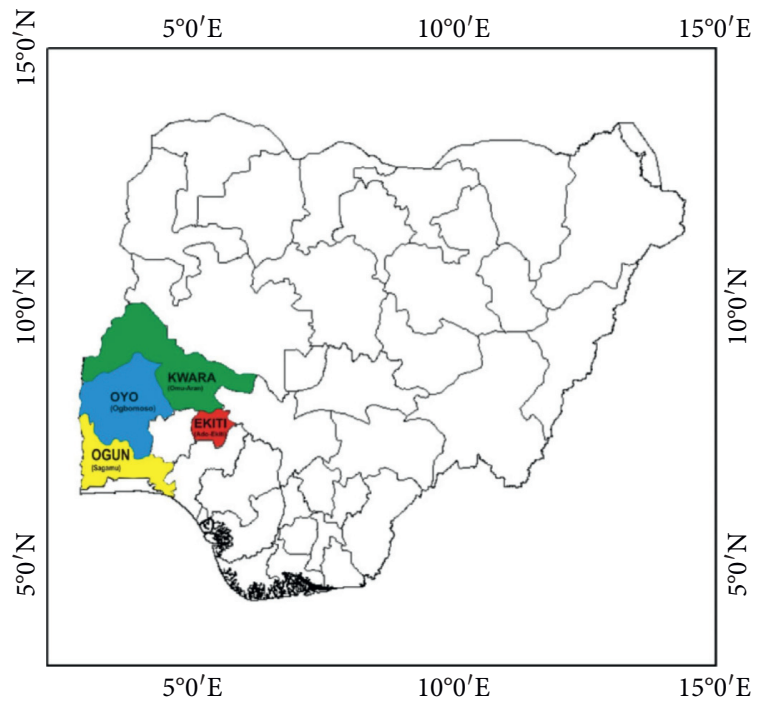

Figure 1: Map of Nigeria showing the study area.

Respondents selected must meet the following criteria: (1) they should be indigenous people of Yoruba; (2) they are sound and knowledgeable in phytotherapy; (3) they are accessible to medicinal plants; (4) they must have used herbs for treating malaria; (5) they are approachable and organized.

2.4. Structured Questionnaire. The structured questionnaire was designed according to the technique of Olorunnisola et al. [22] and Sarquis et al. [23] with slight modification. The moderated questionnaire entails information on respondent biodata, commonly used antimalarial medicinal plants, plant parts frequently used, the most effective herbs from the respondents list, mode of preparation, and common side effects of antimalarial plants.

2.5. Data Collection. The study was piloted for 6 months, from March to August 2019. The mode of data collection was through one-on-one interviews, public discussion, and observation. The interviews were conducted mostly in Yoruba (native) language. The respondents gave the native names of plants and showed the interviewers the available plant samples. Information on the questionnaires was supplied on the spot of interview, and several observations and discussions were conducted prior to completing and cross-checking of the information provided.

2.6. Data Analysis. The antimalarial medicinal plants itemized by the respondents were structured according to the scientific, common, and local names, family, plant part used, and mode of preparation. The malarial diseases' symptoms and probable health effects or body reactions were reported. Data were statistically analysed in percentages using Graphpad Prism software (version 6.0) The comparative significance of a plant species for its ethnopharmacological activity was evaluated with the Index of Use Value (UV) and efficiency level (EL).
2.6.1. Use Value $(U V)$. It is a quantifiable catalogue that denotes the therapeutic importance of each medicinal plant species. It is calculated by $\mathrm{UV}=\Sigma U i / n$, where $\mathrm{Ui}$ is the total number of times plant species is cited and $n$ is the total number of respondents interviewed. UV element helps evaluate plant species frequently mentioned for antimalaria. A high UV denotes plant mentioned mostly by respondents and low for sparingly mentioned [23].

2.6.2. Efficiency Level (EL). It is a qualitative index that signifies the efficacy of a single plant species from the list of plants given as a response by the interviewees. EL is calculated by $\mathrm{CL}=U i$, where $U i$ is the total number of times a particular plant species is mentioned as the most effective from the list of plant species level. EL indicates plant species showing the most effective therapeutic potentials. A high EL denotes the most efficacious plant.

\section{Results and Discussion}

3.1. The Demographic Details of the Informants. A total of 90 interviewees (44 men and 46 women) were involved in this ethnobotanical and ethnopharmacological survey. Demographic details of the interviewees are listed in Table 1. The respective age distribution and the level of education of the respondents are shown in Figure 2.

3.2. The Effectiveness of the Medicinal Plants. In this study, 57 respondents (63\%) strongly agreed and 26 respondents (29\%) agreed that malaria is curable using medicinal herbs while 7 respondents ( $8 \%$ ) were neutral. This denotes the local belief in phytotherapy of malaria. The study site has rich vegetation diversity ranging from creeping plant to shrubs and trees. A large number of these plants are used by the inhabitants in malaria therapy due to persistent spread of malaria in these regions.

3.3. Indigenous Notion of the Study Area on Malaria. The common symptoms of malaria and side effects of antimalarial plants according to the native knowledge of Ado Ekiti, Ogbomoso, Omu Aran, and Sagamu people are detailed in Table 2. Yoruba people identify malaria as "iba" and presumed malaria as a common and seasonal disease. From one-on-one interview and observations, malaria prevalence is significantly high during the rainy season in the study areas. According to the respondents, malaria is caused by long-time exposure to rain, cold, hot sun, stress, and mosquito. They believed that these could disrupt the temperature balance in the body.

Likewise, the respondents were screened to procure knowledge of malaria via the common symptoms they experienced (Figure 3) Fever, body pain, fatigue, and headache are the common symptoms in the study area and are related to temperature balance of the body system. The local people believed that it could be caused by excessive heat and longtime exposure to cold environment which forces the body to produce excessive heat. Moreover, they explained that fever 
TABle 1: Demographic details of the informants $(N=90)$.

\begin{tabular}{lcc}
\hline Biodata & Group of informants & No of informants, $n(\%)$ \\
\hline \multirow{3}{*}{ Age } & $20-39$ years old & $49(54.44)$ \\
& $40-59$ years old & $22(24.44)$ \\
Sex & $60-79$ years old & $15(16.67)$ \\
& $>80$ years old & $04(4.44)$ \\
Education & Male & $44(48.88)$ \\
& Female & $46(51.11)$ \\
& Illiterate (none) & $16(17.78)$ \\
Location & Primary level & $07(7.78)$ \\
& Secondary level & $23(25.56)$ \\
& Tertiary level & $44(48.89)$ \\
& Urban & $54(60.00)$ \\
\end{tabular}

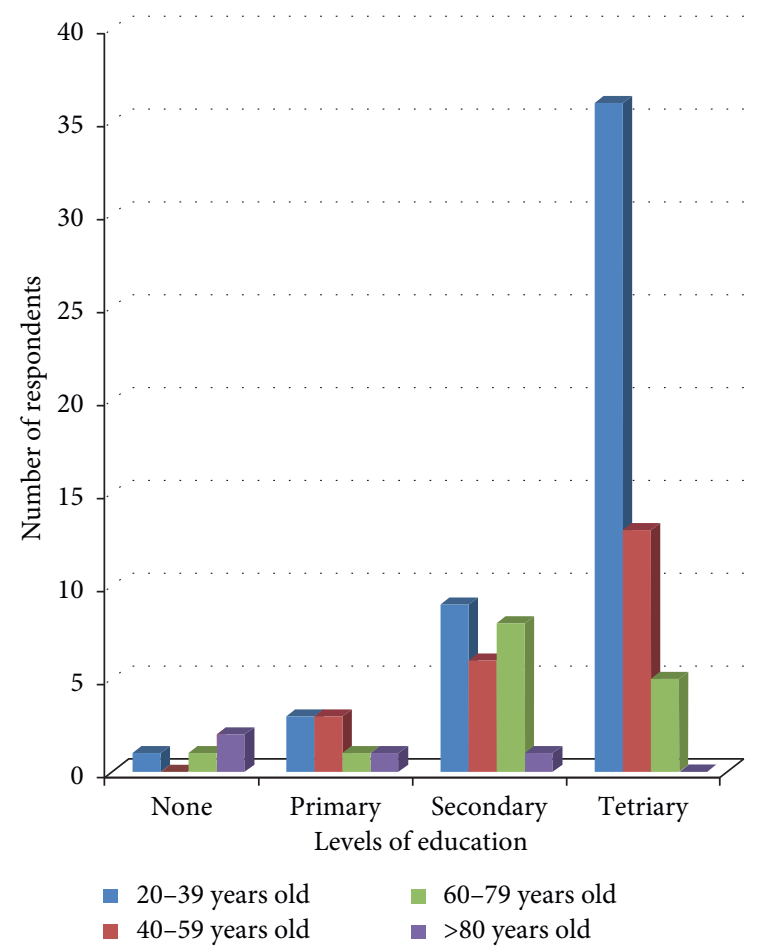

Figure 2: Age distribution and level of education of the respondents.

could lead to other symptoms such as headache, fatigue, body pain, and sweating. According to the respondents, probable ways of preventing malaria include reduction in exposure to rain (cold areas) or sun (hot areas), avoidance of mosquito bites, reduction in workload (stress), constant use of antimalarial herbal drugs, and burning of aromatic antimalarial plants which could pose threats to mosquitoes.

Medicinal plants are universally reported to produce uncharacteristic effects ranging from simple to intricate. The respondents were screened to procure information on common health effects associated with antimalarial herbal drugs. Several reports were obtained, grouped as dizziness, sweating, weakness, frequent urination, itching, and no side effects (Figure 4) However, 15 (70\%) respondents cited other effects produced by medicinal plants on their body systems. The respondents believed that these effects are related to the nature of medicinal plants combined, quantity of herbs taken, period when herb is used, temperature of herbal drugs (warm or cold), season drugs are taken, severity of malaria, and body capacity.

3.4. Assortment of Antimalarial Therapeutic Plants. A total of 59 medicinal plants were cited which belong to 33 families. These are Asteraceae (6), Apocynaceae (5), Anacardiaceae, Annonaceae, Fabaceae, Malvaceae, Meliaceae, Poaceae and Rubiaceae ( 3 each), Phyllanthaceae (2) totaling $48.83 \%$ of the sampled species while Asteraceae, Arecaceae, Asphodelaceae, Boraginaceae, Bromeliaceae, Caricaceae, Crassulaceae, Lamiaceae, Lythraceae, Menispermaceae, Moringaceae, Musaceae, Rutaceae, Sapindaceae, Myrtaceae, Solanaceae, Zingiberaceae, Solanaceae, Meliaceae, Theaceae, Labiatae, Hymenocardiacae, and Zingiberaceae accounted for 22.5\% of families mentioned once (Table 3) The most cited plants include Azadirachta indica (42), Mangifera indica (38), Carica papaya (28), Cymbopogon citratus (27), Cassia fistula (15), Morinda lucida (14), Anacardium occidentale and Vernonia amagdalina (13 each), Helianthus annuus (11), Enantia chlorantha (10), Moringa oleifera (9), Chromolaena odorata, and Psidium guajava (7 each) The efficacy of a plant species is evidenced in its number of citations, thus, becoming spotlight in pharmacological research leading to the discovery of novel antimalarial drugs. However, we cannot rule out the possibility of cultural factors unrelated to efficacy as having impacted the citation rate.

3.5. Used Medicinal Plant Parts. The commonest used parts cited are leaf (46), bark (17), fruits (9), root (9), latex (11), stem (11), and inflorescence (2) (Figure 5) Many antimalarial herbal drugs are commonly prepared from a single plant part, although they could be prepared from the assortment of two or more plant parts. In this survey, leaf and bark were the most cited plant parts contributing to 255 and 101 of the 480 plant parts cited by the respondents. Leaves are the most commonly used plant parts in Nigeria [24,25]. This could be due to the simplicity of the collection, site of synthesizing majority of plant secondary metabolites, and diverse bioactive compounds appraised by preliminary phytochemical investigations of leaves [26-28]. Systematic harvest of leaves has little or no influence on plants survival. This explains the frequent utilization of leaves in herbal recipes [29, 30].

\subsection{Forms of Herbal Drugs' Preparations for Malaria Therapy.} The common herbal drugs' preparations according to the study were categorized as decoction, maceration, infusion, and exudation (Table 3) The most cited methods of preparation are decoction (59\%), maceration (25\%), infusion (9\%), and exudation (7\%) (Figure 6) Decoction was cited 99 times; maceration, 65 times; infusion, 35 times; and exudation, 13 times. Decoction is commonly used in herbal recipes because recipe could be stored, could have long-life span, could be taken orally, and could be used as bath. Due to heat treatment, recipe is safe to administer and more metabolites are believed to be extracted. Maceration is also 
TABLE 2: The common symptoms of malaria and the health effects of antimalarial herbal drugs.

\begin{tabular}{lccc}
\hline Common symptoms of malaria & No of informants, $n(\%)$ & Health effects of antimalarial herbal drugs & No of informants, $n(\%)$ \\
\hline Fever & $25(28)$ & Dizziness & $16(18)$ \\
Fatigue & $33(37)$ & Sweating & $44(49)$ \\
Body pain & $58(64)$ & Weakness & $22(6)$ \\
Vomiting & $6(7)$ & Frequent urination & $24(5)$ \\
Sweating & $26(29)$ & Itching & $5(6)$ \\
Headache & $65(72)$ & No side effects & $36(40)$ \\
\hline
\end{tabular}

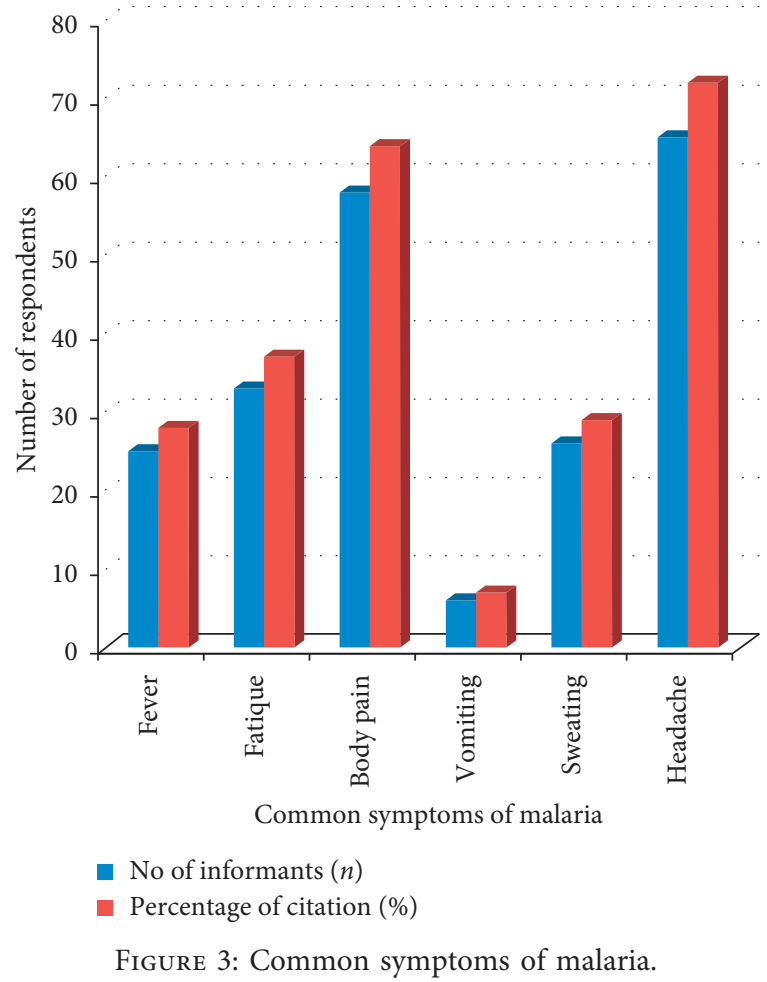

common among the Yorubas. It involves permeation of the plant materials (mostly bark and root) in aqueous (water) or organic (alcohol) solvents.

3.7. Assessment of the Different Indexes. In this study, UVs within 0.47 and 0.11 is appraised as frequently used antimalarial plants by the Yorubas: Azadirachta indica (0.47), Mangifera indica (0.42), Carica papaya (0.31), Cymbopogon citratus (0.3), Cassia fistula (0.17), Morinda lucida (0.16), Anacardium occidentale (0.14), Vernonia amagdalina (0.14), Helianthus annuus (0.12), and Enantia chlorantha (0.11) (Table 3) The most significant plant species are those with high UV and should be compiled for preservation.

The EL appraised the efficacy of a particular plant from the catalogue given by the interviewees. In this study, 11 different medicinal plants were mentioned by the respondents as most efficacious from array of medicinal plants listed. 26 respondents cited $A$. indica and C. fistula while $M$. lucida was cited by 12 respondents; $C$. odorata, 10 respondents; $M$. indica, E. chlorantha, and H. annuus, 8 respondents each; C. citratus (7 respondents); G. arboretum, 4

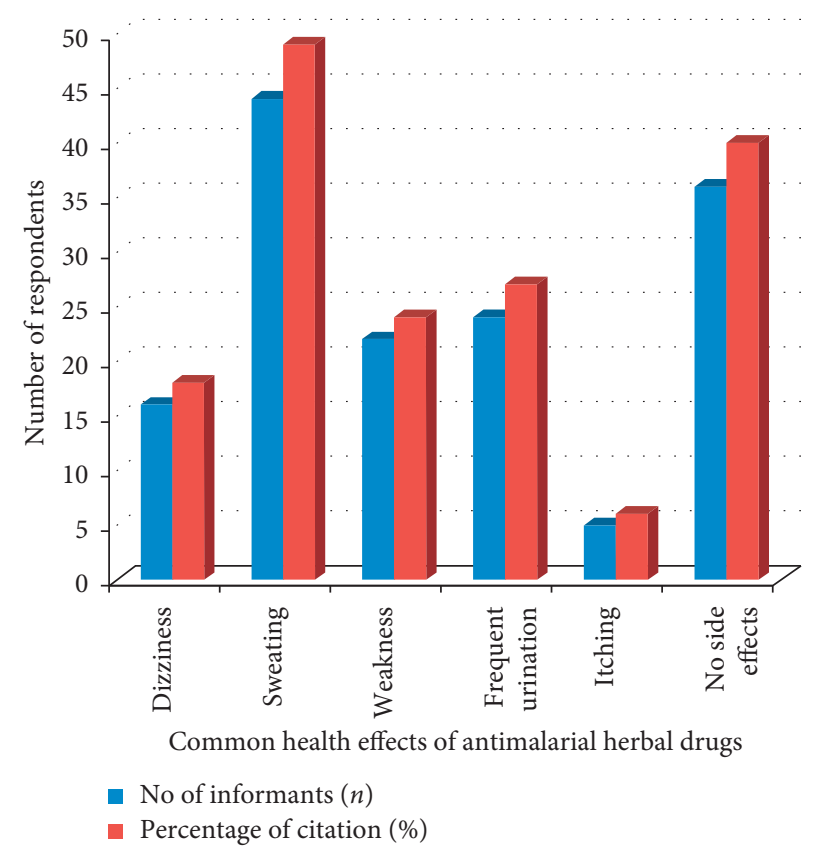

Figure 4: Health effects of antimalarial herbal drugs.

respondents; L. dulcis, 3 respondents; and A. vera, 2 respondents.

The in vitro and in vivo antiplasmodial potency of medicinal plants has been appraised against $P$. falciparum, $P$. berghei, and $P$. yoelii. Some of the plants with exceptional antiplasmodial activities are P. guajava [31], N. latifolia [32], C. citratus [33, 34], U. chamae [35], E. chlorantha [36, 37], O. gratissimum [38], A. leiocarpus [39], P. amarus [40], A. indica [41, 42], C. odorata [43, 44], M. lucida [45, 46], V. amygladina [47], A. boonei 44, 48], A. senegalensis [48], A. occidentale [49, 50], B. ferruginea [51], G. arboretum [48], M. oleifera [39], and S. jollyanum [44].

About four plant species are mentioned for the first time as antimalarial medicinal plant. These plants have a low UV indicating that there is little awareness on these plants in the region. The plants are Cocos nucifera (0.01), Curcuma longa (0.01), Forkia biglobosa (0.01), and Musa acuminate (0.01).

3.8. Antimalarial Assays of Medicinal Plants. Herbal plants are essential part of biodiversity which have proven to ease and remediate several diseases and infections. In tropical African countries, herbal medicine has been an undisputable therapeutic medium as alternative to conventional medicine [52]. In view of this, therapeutic potentials of medicinal 
TABle 3: The medicinal plants used as antimalarial in Nigeria (Omu Aran, Ogbomoso, Ado Ekiti, and Sagamu).

\begin{tabular}{|c|c|c|c|c|}
\hline Botanical name & Local name(s) & Family name & Parts used & $\begin{array}{l}\text { Common method of } \\
\text { preparation }\end{array}$ \\
\hline $\begin{array}{l}\text { (1) Acanthospermum hispidum (starburr, goat } \\
\text { head) }\end{array}$ & Dagunro & Asteraceae & Stem, leaves & Decoction, maceration \\
\hline $\begin{array}{l}\text { (2) Ageratum conyzoides (billygoat-weed, } \\
\text { goatweed, chickweed, whiteweed) }\end{array}$ & Imi-esu & Asteraceae & Leaves & Decoction \\
\hline (3) Anogeissus schimperi & Ayin & Combretaceae & Leaves, bark & Decoction, maceration \\
\hline (4) Aloe vera (Aloe) & Ahon erin & Asphodelaceae & Leaves & Exudate \\
\hline (5) Alstonia boonei (cheese wood, stool wood) & Ahun & & Bark, root & Decoction, infusion \\
\hline (6) Anacardium occidentale (cashew) & Kasu & Anacardiaceae & $\begin{array}{l}\text { Stem, leaves, } \\
\text { bark }\end{array}$ & $\begin{array}{l}\text { Decoction, infusion, } \\
\text { maceration }\end{array}$ \\
\hline (7) Ananas comosus (pineapple) & Eso alade, ope oyinbo & Bromeliaceae & Unripe fruit & Exudate, decoction \\
\hline $\begin{array}{l}\text { (8) Annona senegalensis (African custard apple, } \\
\text { wild soursop) }\end{array}$ & Arere & Annonaceae & Root & Infusion, maceration \\
\hline $\begin{array}{l}\text { (9) Azadirachta indica (neem, Indian lilac, } \\
\text { nimtree) }\end{array}$ & Dogoyaro, eka ebo & Meliaceae & $\begin{array}{l}\text { Bark, leaves, } \\
\text { root, }\end{array}$ & $\begin{array}{l}\text { Decoction, infusion, } \\
\text { maceration, }\end{array}$ \\
\hline $\begin{array}{l}\text { (10) Bridelia exaltata (scrub ironbark, brush } \\
\text { ironbark) }\end{array}$ & Ira, iran oda, ira eju & Phyllanthaceae & Bark & Decoction, maceration \\
\hline $\begin{array}{l}\text { (11) Bryophyllum pinnatum (cathedral bells, } \\
\text { miracle leaf, life plant) }\end{array}$ & Abamoda & Crassulaceae & Leaves & Decoction \\
\hline $\begin{array}{l}\text { (12) Calotropis procera (sodom apple, rubber } \\
\text { bush) }\end{array}$ & Bomu-bomu & Apocynaceae & Leaves, fruit & Decoction, exudate \\
\hline (13) Camellia sinensis (tea bush) & Werepe & Theaceae & Leaves & Decoction \\
\hline (14) Capsicum frutescens (chili pepper) & Ata-ijosi, ata-wewe & Solanaceae & Seed/fruit & Maceration, exudate \\
\hline (15) Carica papaya (pawpaw) & Ibepe & Caricaceae & $\begin{array}{l}\text { Fruit, leaves, } \\
\text { root }\end{array}$ & Infusion, maceration \\
\hline $\begin{array}{l}\text { (16) Cassia fistula (golden shower, Indian } \\
\text { laburnum) }\end{array}$ & Igi kasia & Fabaceae & $\begin{array}{l}\text { Stem, leaves, } \\
\text { bark }\end{array}$ & Decoction, infusion \\
\hline (17) Ceiba pentandra (kapok tree) & Iroko & Malvaceae & Leaves & Decoction \\
\hline $\begin{array}{l}\text { (18) Chromolaena odorata (siam weed, devil } \\
\text { weed, Christmas bush) }\end{array}$ & Ewe akintola, awolowo, & Asteraceae & Leaves, stem & Decoction \\
\hline $\begin{array}{l}\text { (19) Citrus aurantifolia (lime, key lime, west } \\
\text { Indian lime, bartenders lime) }\end{array}$ & Orombo & Rutaceae & Leaves, fruit & Decoction, exudates \\
\hline $\begin{array}{l}\text { (20) Citrus aurantium (sour orange, bigarade } \\
\text { orange, bitter orange) }\end{array}$ & Osan jagan & Rutaceae & Leaves, fruit & Decoction, exudates \\
\hline (21) Citrus limon (lemon) & Osan wewe, ilamuna & Rutaceae & $\begin{array}{l}\text { Stem, root, } \\
\text { leaves, fruit }\end{array}$ & Decoction, \\
\hline (22) Citrus paradise (grape) & Ajara & & & Exudates \\
\hline (23) Cocos nucifera (coconut) & Agbon & & Fruit shell & Decoction, infusion \\
\hline (24) Curcuma longa (turmeric) & Ata-ile pupa & Zingiberaceae & Fruit & Decoction, maceration \\
\hline $\begin{array}{l}\text { (25) Cymbopogon citratus (lemongrass, Malabar } \\
\text { grass) }\end{array}$ & $\begin{array}{l}\text { Oka oyinbo, ewe tea, } \\
\text { koko oba }\end{array}$ & Poaceae & Leaves, & Decoction \\
\hline (26) Enantia chlorantha (African yellow wood) & $\begin{array}{c}\text { Awopa, dokita igbo, osu } \\
\text { pupa }\end{array}$ & Annonaceae & Leaves, bark & Decoction, maceration \\
\hline $\begin{array}{l}\text { (27) Parkia biglobosa (African locust bean, } \\
\text { eggplant) }\end{array}$ & Igi iru, sumbala & Fabaceae & Leaves, bark & Decoction, maceration \\
\hline (28) Gardenia ternifolia & Oruwon, Gangan & Rubiaceae & Leaves & Decoction \\
\hline (29) Gongronema latifolium (bush buck) & Arokeke & Apocynaceae & Leaves, bark & Decoction, maceration \\
\hline (30) Gossypium arboretum (cotton plant) & Owu & Malvaceae & Leaves & Decoction \\
\hline (31) Helianthus annuus (sunflower) & $\begin{array}{l}\text { Fufulele, June 12, } \\
\text { agunmoniye }\end{array}$ & Asteraceae & Leaves & Decoction, \\
\hline $\begin{array}{l}\text { (32) Heliotropium indicum (Indian heliotrope, } \\
\text { turnsole, English combs comb) }\end{array}$ & $\begin{array}{l}\text { Agogo igun, ogbe akuko, } \\
\text { akuko omade }\end{array}$ & Boraginaceae & $\begin{array}{l}\text { Stems, leaves, } \\
\text { root, bark }\end{array}$ & $\begin{array}{l}\text { Decoction, } \\
\text { maceration, infusion }\end{array}$ \\
\hline (33) Hibiscus sabdariffa (Roselle, carcade) & & Malvaceae & & Decoction, infusion \\
\hline (34) Hoslunda opposite & Efirin & Labiatae & Leaves & Decoction \\
\hline (35) Hymenocardia acida & Aboopa, orupa & Hymenocardiacae & Leaves & Decoction \\
\hline (36) Khaya grandifoliola (African mahogany) & Oganwo & Meliaceae & Bark & Maceration \\
\hline $\begin{array}{l}\text { (37) Lactuca canadensis (Canada lettuce, tall } \\
\text { lettuce) }\end{array}$ & Yanrin & Asteraceae & Leaves & Decoction \\
\hline (38) Landolphia dulcis & Ibobo, ibo & Apocynaceae & Leaves & Decoction \\
\hline
\end{tabular}


TABle 3: Continued.

\begin{tabular}{|c|c|c|c|c|}
\hline Botanical name & Local name(s) & Family name & Parts used & $\begin{array}{c}\text { Common method of } \\
\text { preparation }\end{array}$ \\
\hline $\begin{array}{l}\text { (39) Lawsonia inermis (Henna, Egyptian privet, } \\
\text { cypress shrub) }\end{array}$ & Laali & Lythraceae & Leaves & Decoction \\
\hline (40) Lecaniodiscus cupanioide & Akika & Sapindaceae & Leaves & Decoction \\
\hline (41) Mangifera indica (mango) & Mangoro, oro & Anacardiaceae & $\begin{array}{l}\text { Bark, stem, } \\
\text { leaves }\end{array}$ & $\begin{array}{l}\text { Decoction, } \\
\text { maceration, infusion }\end{array}$ \\
\hline (42) Morinda lucida (brimstone-tree) & Oruwo & Rubiaceae & Leaves & Decoction \\
\hline (43) Moringa oleifera (moringa, drumstick) & Ewe ile, igbale igi iyanu & Moringaceae & Leaves, bark & Decoction, maceration \\
\hline (44) Musa acuminate (banana) & Ogede & Musaceae & Leaves & Decoction \\
\hline (45) Nauclea latifolia (African peach) & Egbo igbesi & Rubiaceae & $\begin{array}{l}\text { Leaves, root } \\
\text { bark }\end{array}$ & Decoction \\
\hline $\begin{array}{l}\text { (46) Ocimum gratissimum (clove basil, scent } \\
\text { plant, African basil) }\end{array}$ & Efirin, aramogbo & Lamiaceae & Leaves, stem & Decoction \\
\hline $\begin{array}{l}\text { (47) Panicum miliaceum (proso millet, hog } \\
\text { millet) }\end{array}$ & Poporo oka, oka baba & Poaceae & Stem & Decoction, maceration \\
\hline (48) Parquetina nigrescens & Igi ogbo & Apocynaceae & Leaves & Decoction \\
\hline $\begin{array}{l}\text { (49) Pennisetum purpureum (elephant grass, } \\
\text { napier grass, Uganda grass) }\end{array}$ & Eèsún, eèsún funfun & Poaceae & Leaves & Decoction \\
\hline (50) Phyllanthus amarus & Eyin olobe & Phyllanthaceae & Leaves & Decoction \\
\hline (51) Senna alata (candle bush, candletree) & Asunwon oyinbo & Fabaceae & $\begin{array}{l}\text { Leaves, flower, } \\
\text { fruit }\end{array}$ & Decoction, maceration \\
\hline $\begin{array}{l}\text { (52) Sorghum bicolor (durra, great millet, } \\
\text { jowari) }\end{array}$ & Poroporo okababa & Poaceae & Stem & Decoction \\
\hline (53) Sphenocentrum jollyanum & Aduro koko, akerejupon & Menispermaceae & Root & Decoction, maceration \\
\hline $\begin{array}{l}\text { (54) Spondias mombin (yellow mombin, hog } \\
\text { plum) }\end{array}$ & Okika, akika, iyeye & Anacardiaceae & Leaves & Decoction \\
\hline (55) Swietenia mahagoni (mahogany) & & Meliaceae & Bark & Decoction, maceration \\
\hline $\begin{array}{l}\text { (56) Tridax procumbens (coatbuttons, tridax } \\
\text { daisy) }\end{array}$ & Igbalode, muwagun & Asteraceae & Leaves & Decoction \\
\hline (57) Uvaria chamae (finger root, bush banana) & Eru, eruju, akisan, oko aja & Annonaceae & $\begin{array}{l}\text { Stem, leaves, } \\
\text { bark }\end{array}$ & Decoction, maceration \\
\hline $\begin{array}{l}\text { (58) Vernonia amygdalina (bitter leaf) } \\
\text { (59) Swietenia mahagoni (mahogany) }\end{array}$ & Onugbo, ewuro & $\begin{array}{l}\text { Asteraceae } \\
\text { Meliaceae }\end{array}$ & $\begin{array}{l}\text { Leaves, root, } \\
\text { Bark }\end{array}$ & $\begin{array}{l}\text { Decoction, maceration } \\
\text { Decoction, maceration }\end{array}$ \\
\hline
\end{tabular}

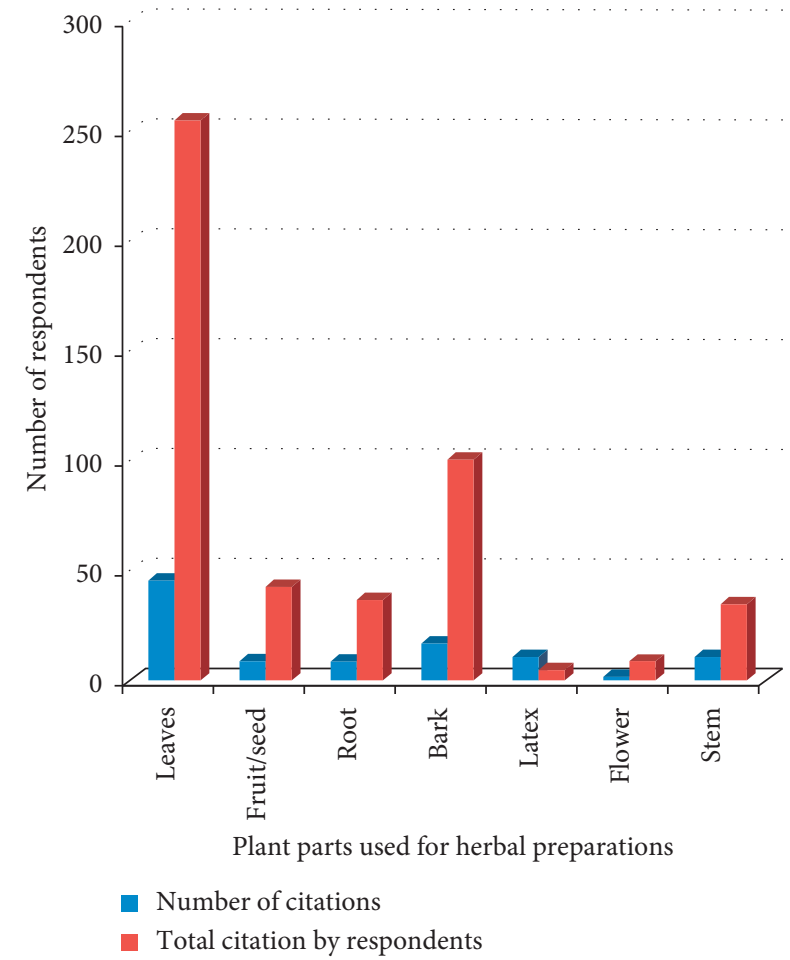

Figure 5: Plant parts used for herbal preparations. plants are appraised against numerous diseases such as malaria, diabetes, cancer, ulcer, hypertension, and viral infections [53]. Generally, pharmacological activities of medicinal herbs could be linked to the existence of secondary metabolites like cardiac glycosides, saponins, tannins, flavonoids, terpenoids, and alkaloids [18]. Several plants have been explored for their antimalarial potency with curative basis exploited from ethnopharmacological beliefs (Table 4) [76].

Cymbopogon citratus. Lemongrass (Poaceae) is a perennial grass, evenly distributed in the tropic region, South and Central America, and has an outstanding profile in the folk medicine [17]. The antimalarial potential of aqueous leaf extracts of $C$. citratus assessed on twenty-five Swiss albino mice demonstrated significant prophylactic and chemotherapeutic potency against mice infected with $0.2 \mathrm{ml} \mathrm{O}{ }^{+}$ human parasitized blood of $P$. falciparum after $72 \mathrm{~h}$. Significant inhibition was observed in parasitaemia level of blood of infected mice [55]. A larvicidal test of geranial, an essential oil in C. citratus, was evaluated against Anopheles funestus (mature larvae) and P. falciparum according to the WHO standard procedure. Prominent activities were recorded at $\mathrm{LD}_{50}(35.5 \mathrm{ppm}$ and $34.6 \mathrm{ppm})$ after $6 \mathrm{~h}$. Geranial also displayed significant antiplasmodial activity with $\mathrm{IC}_{50}$ 


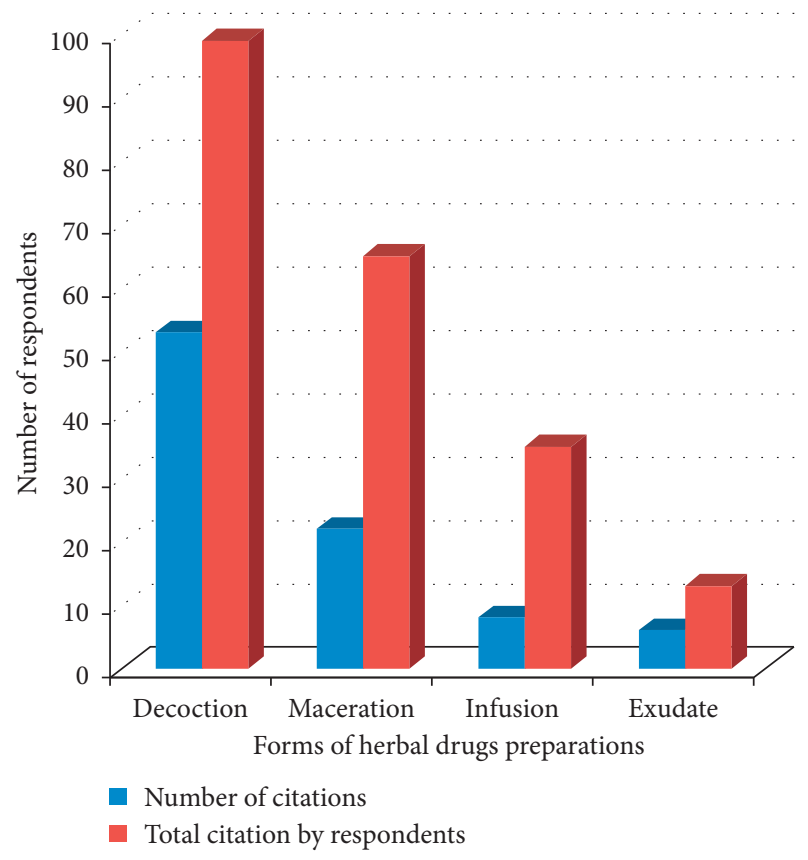

FIGURE 6: Forms of herbal drugs preparations for malaria therapy.

$(4.2 \pm 0.5 \mathrm{~g} / \mathrm{mL})$ when assessed by the radioisotopic method. Geranial could serve as effective natural biocides for combating the larvae of malaria vectors [61]. The antiplasmodial activity of aqueous leaf and root extracts of C. citratus (200, 400 , and $800 \mathrm{mg} / \mathrm{kg}$ ) and chloroquine $(5 \mathrm{mg} / \mathrm{kg}$ ) was examined against $P$. berghei in mice using 4-day suppressive test model at $P<0.05$. A dose-dependent suppressive pattern was observed with chloroquine and $800 \mathrm{mg} / \mathrm{kg}$ (aqueous root extract) [67]. C. citratus plant displayed significant antimalarial activity than herbal concoction or chloroquine $(3200 \mathrm{mg} / \mathrm{kg})$ (control) when used as a prophylactic treatment against CBA/Ca mice with patent $P$. berghei ANKA or $P$. chabaudi AS at doses of 1600 and $3200 \mathrm{mg} / \mathrm{kg}$. In addition, the synergetic activity of chloroquine and $C$. citratus plant exhibited high activity than chloroquine alone against $P$. berghei. The antimalarial activity of entire C. citratus plant aids inevitable efforts to developing whole plant remedies for the treatment of malaria [65].

Morinda lucida. The antimalarial investigation of partly purified cysteine-stabilised peptide extracts of $M$. lucida leaf was assessed in vitro against $P$. falciparum W2 and its activities on certain liver and erythrocyte antioxidant parameters in $P$. berghei NK65-infected mice. Low activities were observed in P. falciparum W2 (IC50: $>50 \mu \mathrm{g} / \mathrm{ml}$ ); however, in vivo activity against $P$. berghei led to $51.52 \%$ reduction in parasitaemia on $96 \mathrm{~h}$ after inoculation and considerably decreased $(P<0.05)$ malondialdehyde concentrations in the liver and erythrocyte at high doses in contrast to untreated controls [60]. N-Hexane and chloroform fractions of M. lucida leaf extract conducted using standard techniques showed significant activities at $0.6 \mathrm{mg} /$ $\mathrm{ml}$ [64]. The antimalarial activities of $M$. lucida investigated in $P$. berghei-infected mice exhibited dose-dependent chemosuppression of 39.8-90.5 which show pronounced activities than quinine [58].
Enantia chlorantha. Enantia chlorantha Oliver (or Annickia chlorantha) belongs to Annonaceae family, socalled Awopa, Osu pupa or Dokita igbo, Eru meru, Kakerim, and Erenba-vbogo in Nigeria. It is dense and widely distributed in Nigeria, Angola, Gabon, Cameroon, and Congo [77]. Oral administration of aqueous extract of E. chlorantha inhibited Plasmodium yoelii in mice at 0.2 to $150 \mathrm{mg} / \mathrm{ml}$ while ethanolic extract inhibited the parasite at dose of 0.05 to $0.5 \mathrm{mg} / \mathrm{g}$. The ethanolic and aqueous extracts have $\mathrm{ED}_{50}$ values of $0.34 \mathrm{mg} \cdot \mathrm{g}^{-1}$ and $6.9 \mathrm{mg} \cdot \mathrm{g}^{-1}$ which are schizonticidal in the mode of action. The activities could be linked to the presence of saponins, tannins, simple sugars, and alkaloids [78]. Synergic reactions of E. chlorantha with $N$. latifolia and A. altilis were reported to display significant antimalarial and prophylactic activities. This justifies the ethnomedical practice of combination of antimalarial herbal therapies in combating acute or chronic malaria [63].

Aloe vera. The methanolic extracts of Aloe vera were assessed in vivo for its antiplasmodial potency against $P$. falciparum strain with $50 \%$ inhibition of 32 to $77 \mu \mathrm{g} / \mathrm{ml}$. The anthrone C-glucoside homonataloin isolated inhibited the strains with activity of $13.46 \pm 1.36 \mu \mathrm{g} / \mathrm{ml}\left(\mathrm{IC}_{50}\right)$; similarly, homonataloin displayed activities of $107.20 \pm 4.14 \mu \mathrm{g} / \mathrm{ml} \quad\left(\mathrm{IC}_{50}\right)$ [79]. C-glycosylated anthrones, that is, nataloin and 7-hydroxyaloin, two isolated compounds in Aloe pulcherrima, displayed significant dose-independent activities on plasmodia strain using 4-day suppressive test. Pronounced activity of $56.2 \%$ was observed at $200 \mathrm{mg} / \mathrm{kg} /$ day in $48 \mathrm{~h}$, which support the ethnomedical claims of the plant [80].

Carica papaya. The antimalarial property of Carica papaya leaf extracts was screened against $P$. falciparum 3D7 and $\operatorname{Dd} 2$ strains using bioassay-guided fractions and dichloromethane extract. The petroleum ether and chloroform fractions of C. papaya fruit and root assessed in vivo for antimalarial activity against early $P$. berghei infection in mice displayed pronounced chemosuppressive effect at $P<0.001$. Significant activities were observed in petroleum ether fractions (61.78\%) compared to $48.11 \%$ of chloroform fraction [71]. The synergistic effects displayed by the administration of C. papaya and V. amygdalina in ameliorating plasmodium infection in mice showed significant result at $P<0.05$. The oral administration significantly surged the $\mathrm{RBC}$ and PCV renaissance when compared to the disease control. This underlined the importance of plants in conventional therapy of malaria infection [68]. Ethanolic leaf extract of C. papaya was appraised on chloroquine-sensitive and chloroquine-resistant strains of P. falciparum. The extracts significantly inhibited the activities of both plasmodium strains with $\mathrm{IC}_{50}=40.75 \%, 36.54 \%, 25.30 \%$, and $18.0 \%$ for chloroquine-sensitive and $\mathrm{IC}_{50}=50.23 \%, 32.50 \%$, $21.45 \%$, and $23.12 \%$ for chloroquine-resistance plasmodium strains [81].

Azadirachta indica. Azadirachta indica extract is appraised to contain bioactive compounds which dictate its potencies against $P$. vivax and $P$. falcifarum [82]. Ethanolic leaf extracts assessed in vivo absolutely inhibited $P$. berghei growth, at azadirachtin dosage of $50 \mathrm{mg} / \mathrm{kg}$ mouse body 


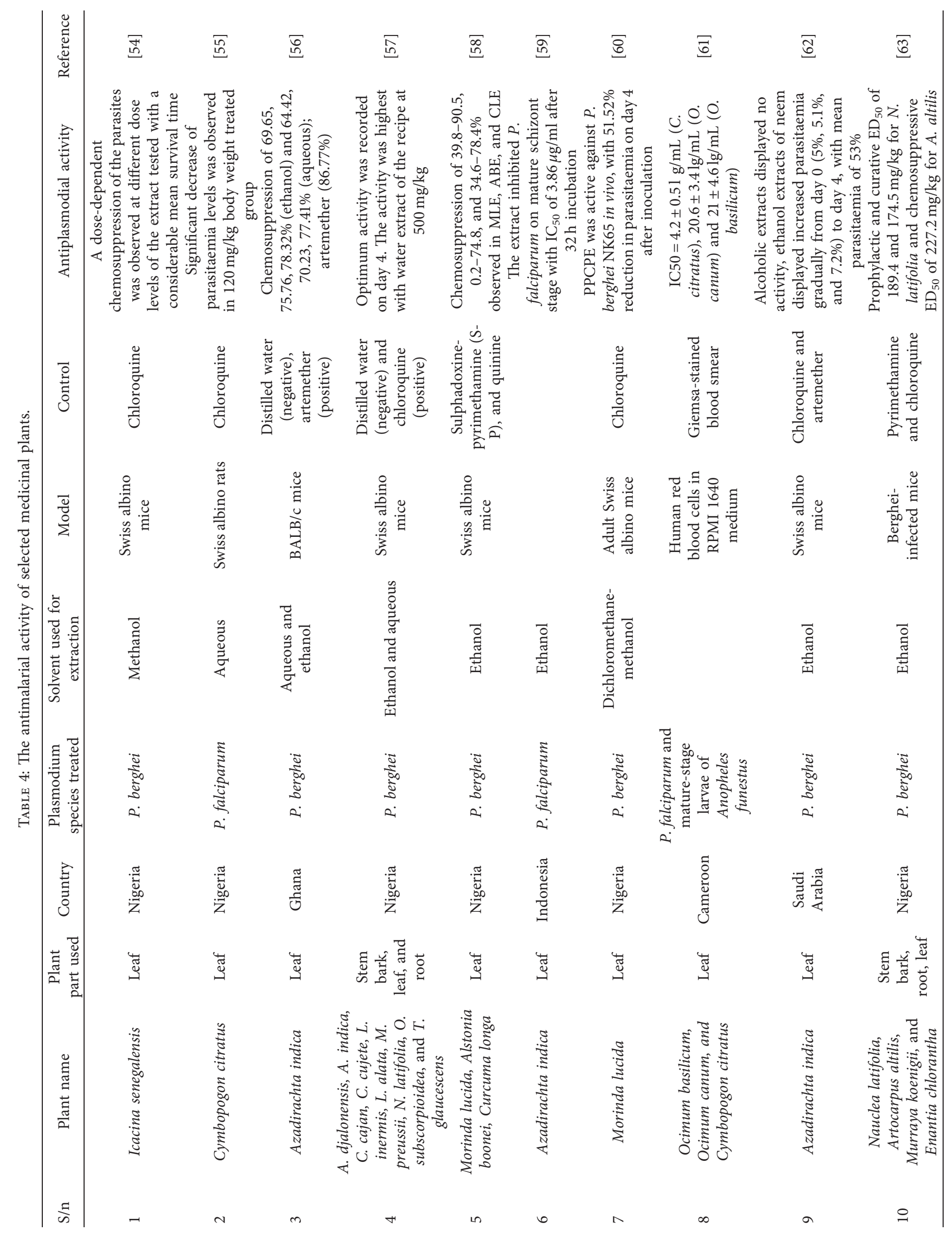




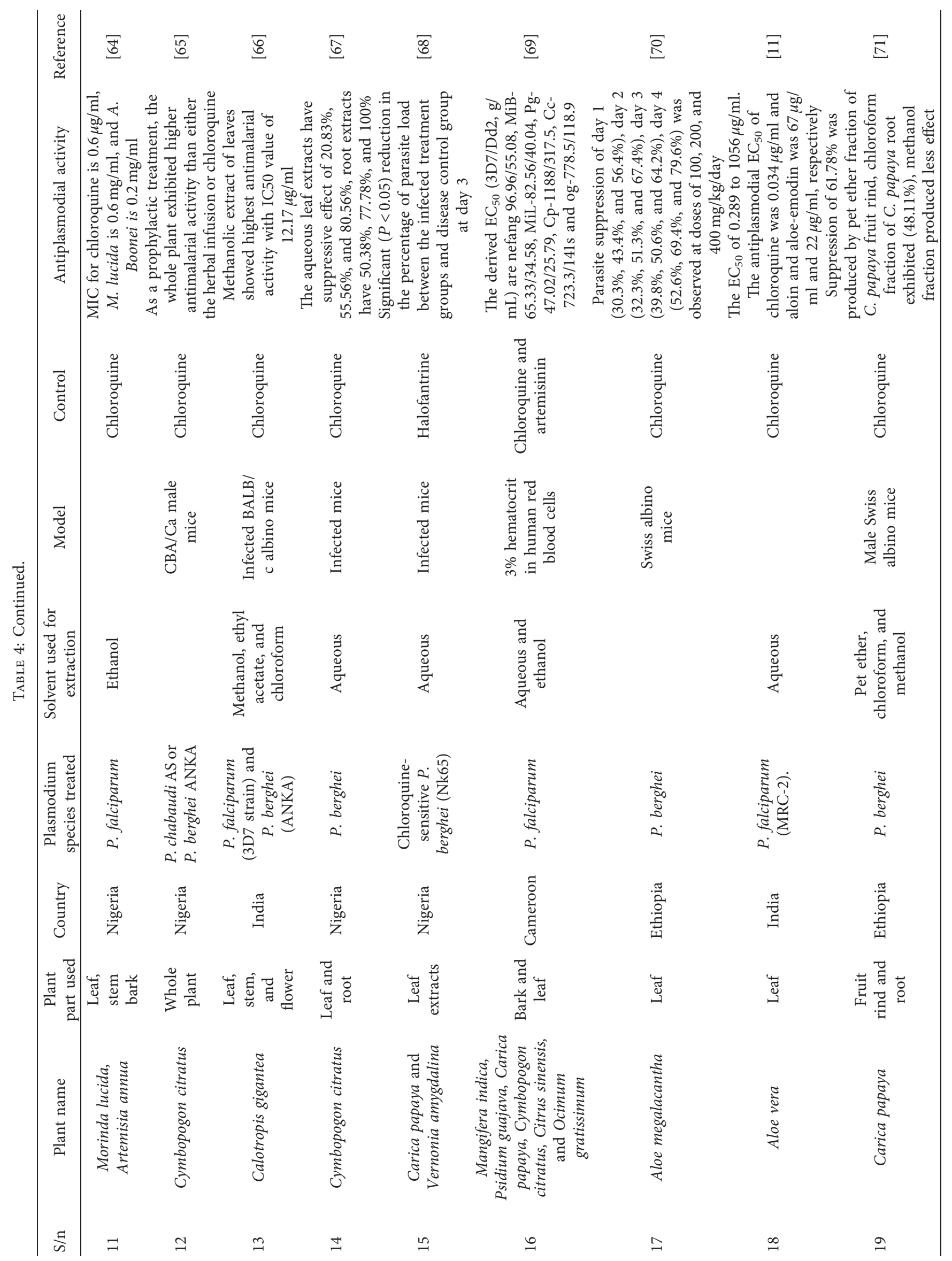




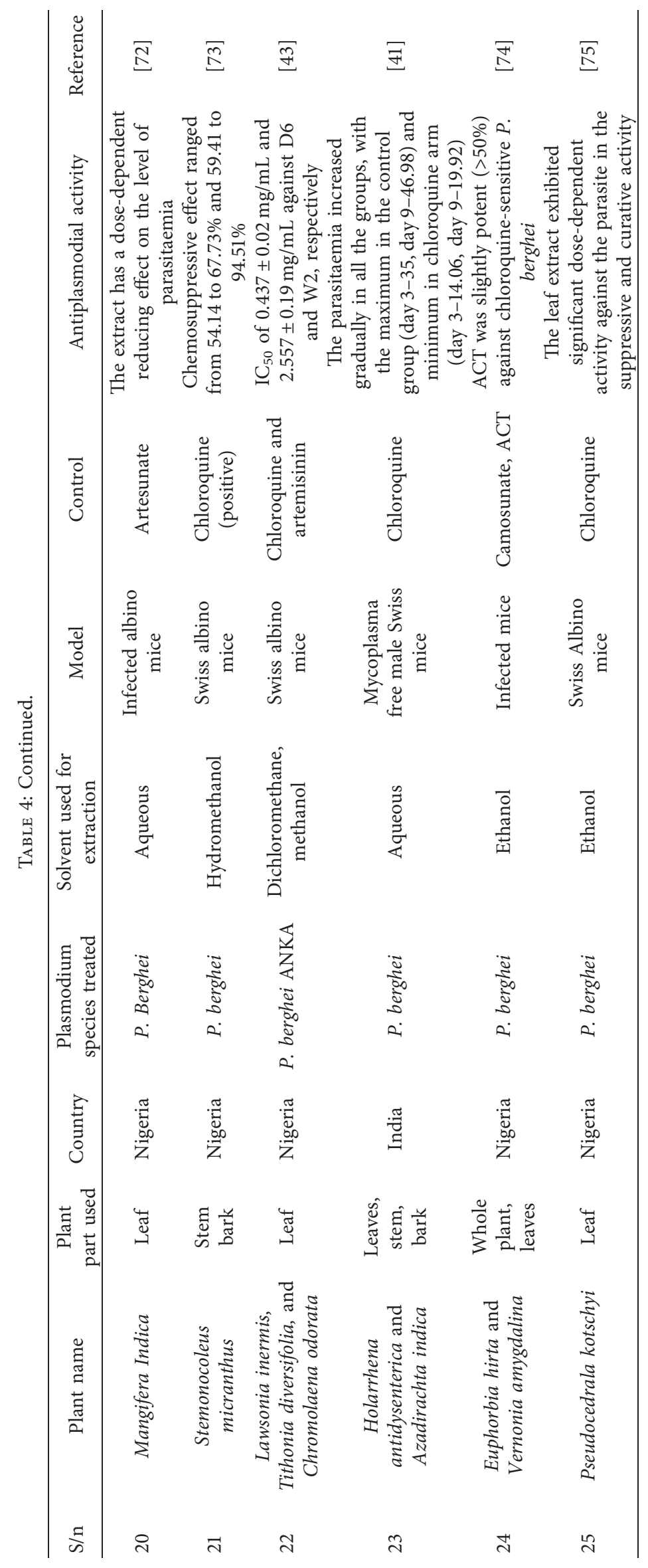


TABLE 5: The isolated compounds from medicinal plants used as antimalarial.

1

Morinda lucida

Asperulosidic acid

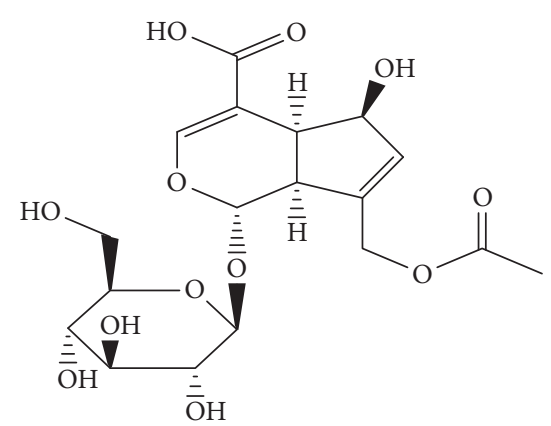

[46]

(


TABLE 5: Continued.

\begin{tabular}{llll}
\hline S/n Name of plant & Phytochemical compounds & Structure & Reference
\end{tabular}

6

Azadirachta indica

Gedunin

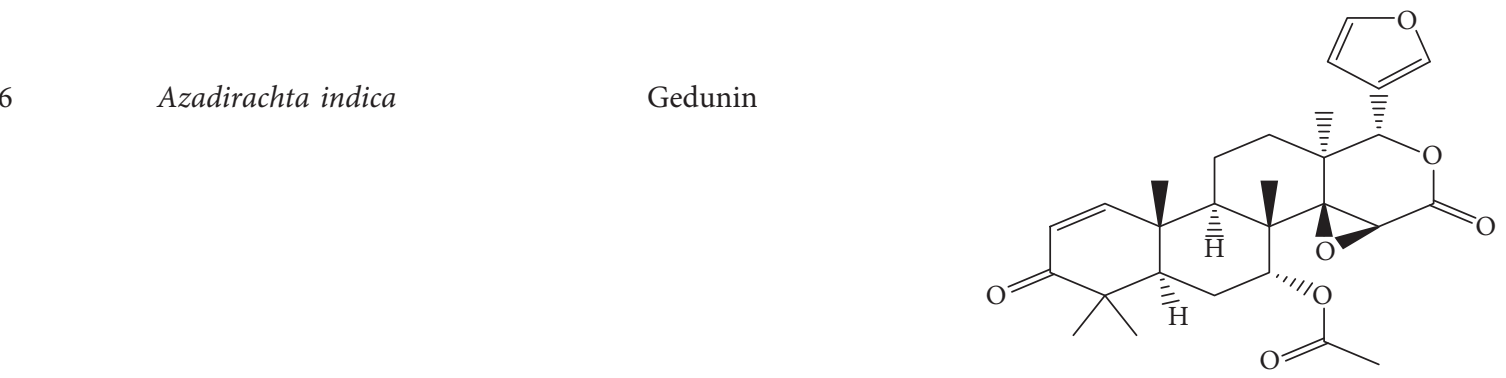

[86]

$7 \quad$ Morinda lucida

Asperuloside
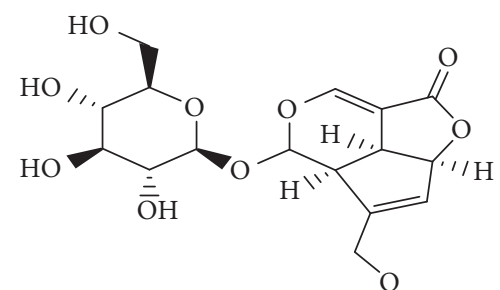

[46]

0

8

Aloe vera

7-Hydroxyaloin B<smiles>O=C1c2c(O)cc(CO)cc2C(C2OC(CO)C(O)C(O)C2O)c2ccc(O)c(O)c21</smiles>

$[79,80]$ 7-Hydroxyaloin $B$

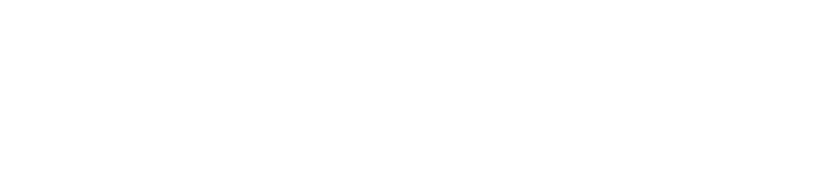

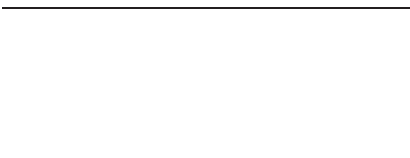

9

Khaya grandifoliola

Methyl angolensate

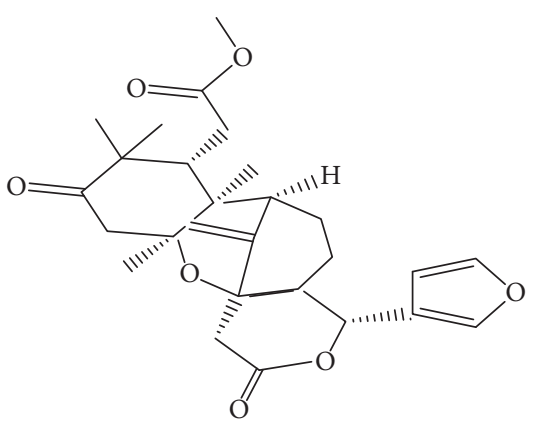


TABle 5: Continued.

\begin{tabular}{llll}
\hline S/n Name of plant & Phytochemical compounds & Structure & Reference
\end{tabular}

10

Khaya senegalensis

Fissinolide

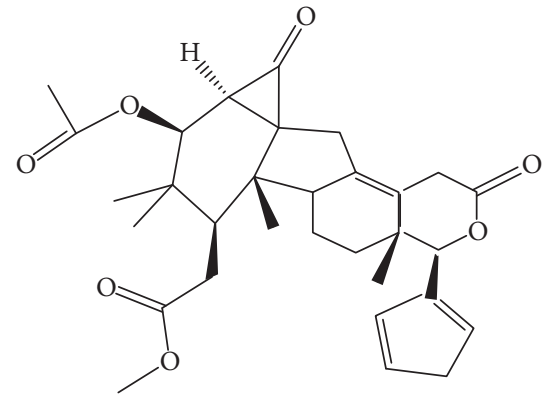

$[88]$

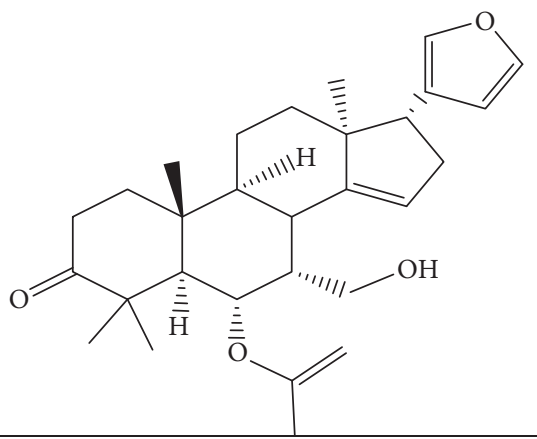

[89]

Meldenin

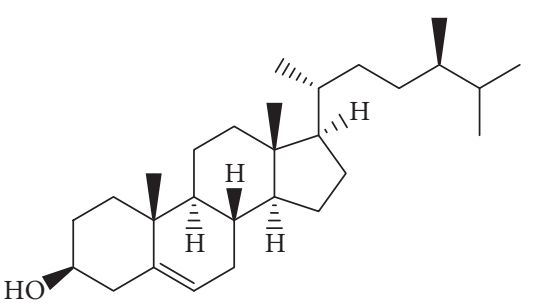

[46]
12

Morinda lucida

Campesterol
OH

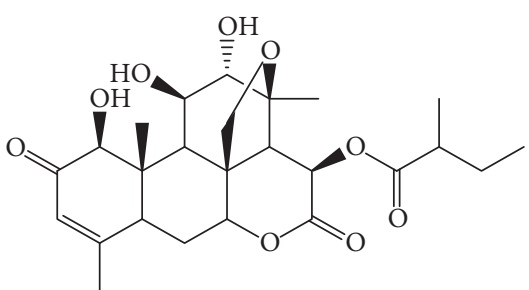

Simalikalactone D 
Table 5: Continued.

S/n Name of plant $\quad$ Phytochemical compounds $\quad$ Structure Reference
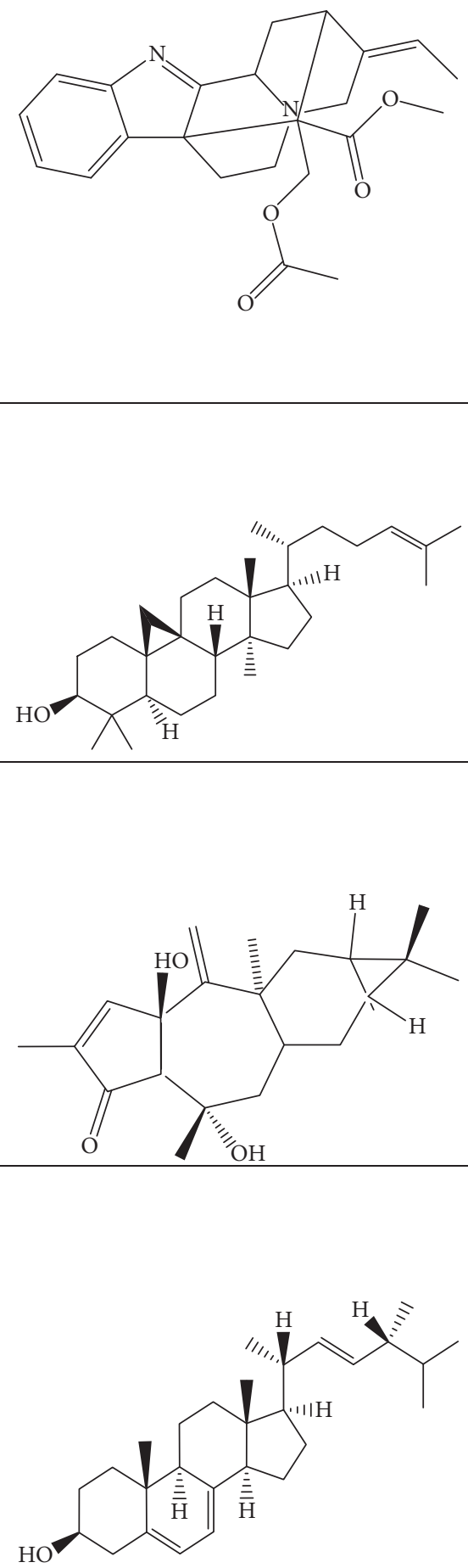
TABle 5: Continued.

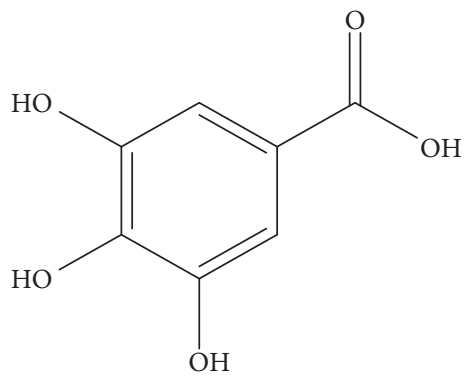

[92]
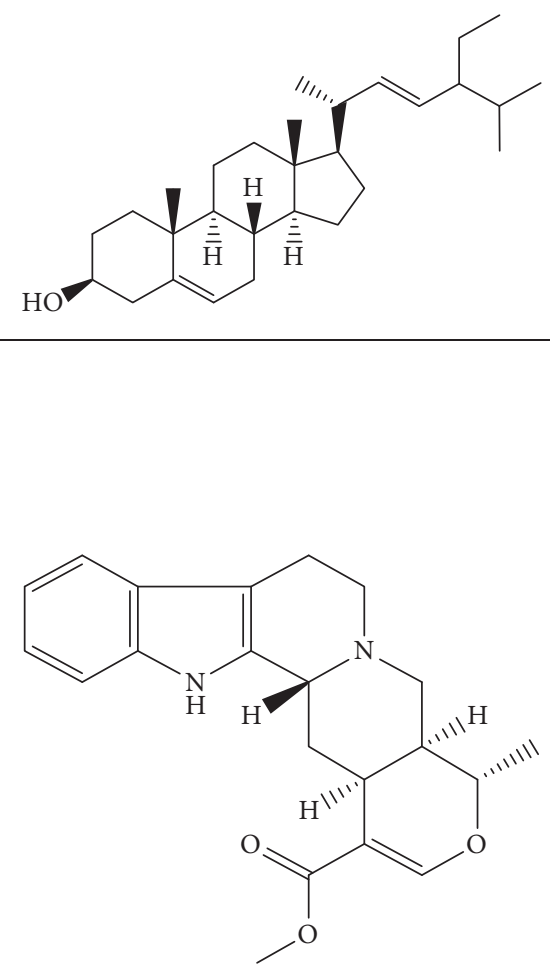
TABLE 5: Continued.

S/n Name of plant $\quad$ Phytochemical compounds $\quad$ Structure

21

Diospyros conocarpa
Mangiferolic acid

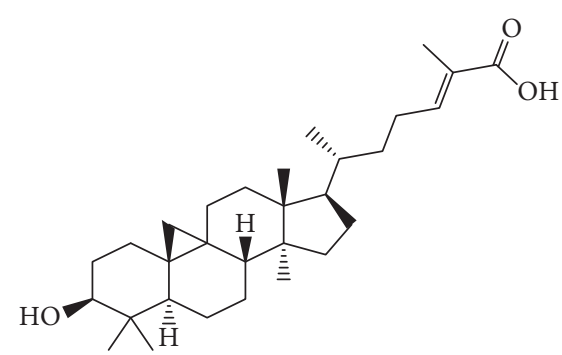

Antrocarine A

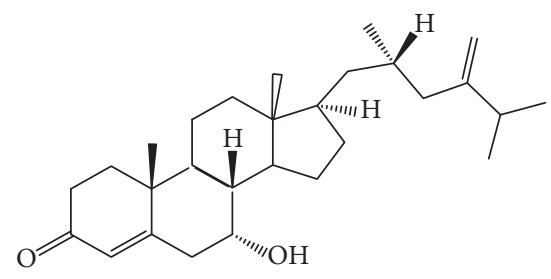

Anacardic acid
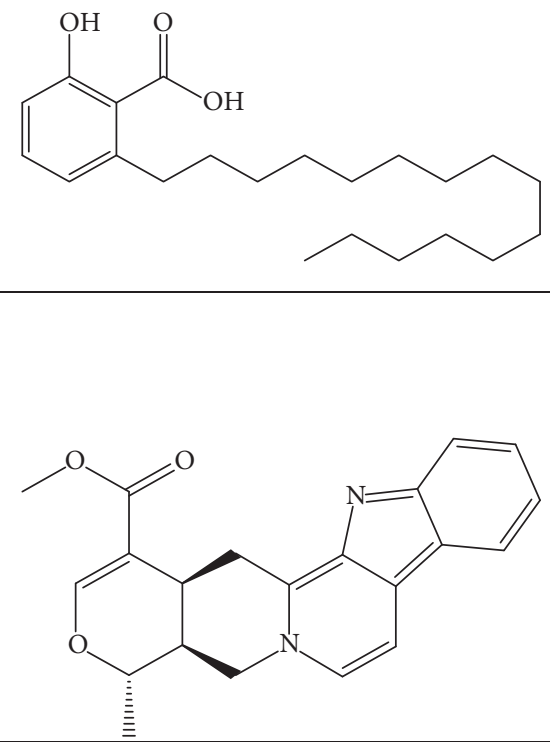
TABLE 5: Continued.

\begin{tabular}{llll}
\hline S/n Name of plant & Phytochemical compounds & Structure & Reference \\
\hline
\end{tabular}

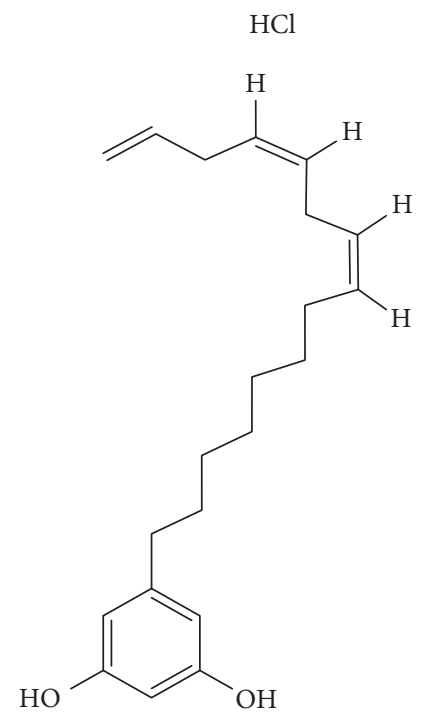

weight [83]. The in vivo antiplasmodial potency of aqueous and ethanolic leaf extracts was examined in $P$. berghei-infected BALB/c mice at dosage of 50 to $200 \mathrm{mg} / \mathrm{kg} /$ day. Both extracts exhibited significant antiplasmodial potency in a dose-dependent technique which could be due to the active antiplasmodial compounds screened [56].

\section{Conclusion and Future Prospects}

Malaria is a universal civic health peril, and recent drug resistance of the parasite is a persistent concern. This study shows that a highly diverse set of native medicinal herbs is currently used for the management of malaria in Nigeria. Based on the results, there is substantial indication that the traditional use of antimalarial medicinal plants by Yoruba ethnics (studied areas) is driven by important therapeutic agents, which could be elucidated structurally and further established by in vitro or in vivo investigations. In recent times, the growing interest in phytoremediation of malaria led to the isolation and characterization of bioactive compounds in medicinal plants (Table 5) The isolation, characterization, and quantification of these compounds were appraised via chromatographic and spectrophotometric methods. Likewise, different assays such as susceptibility microassay technique [95], four day suppressive test [96], 96-well microtiter plate format SYBR green florescence assay [97], and LDH method [98] are used to appraise the antiplasmodial potential of plant extracts (Table 4).

Several modes of preparation, usage factors, health risks, and countermeasures on the use of antimalarial herbal drugs should be systematically examined through advanced scientific approaches. This will aid in the identification and authentication of therapeutic potency of antimalarial compounds isolated from medicinal herbs, thereby promoting its global relevance as efficacious and safe antimalarial plants in primary health care. Individuals, societies, sociogroups, and governmental and nongovernmental organizations should devise plans which could assist in the conservation of these medicinal plants in order to prevent their extermination and exploitation of indigenous populations, as well as considerations for cultural disruptions should one or more of these plant species become a valuable resource. In the meantime, the outcomes of this study serve as a platform of appraisal for indigenous claims of medicinal plants as effective antimalarial drugs in Nigeria and the world as a whole.

\section{Data Availability}

The datasets used and/or analysed during the current study are available in the manuscript and others not included are available from the corresponding author upon request.

\section{Conflicts of Interest}

The authors declare that there are no conflicts of interest regarding the submission and publication of this article.

\section{Authors' Contributions}

All authors designed the experiment, administered the questionnaires, and analysed and discussed the data obtained. 


\section{Acknowledgments}

The authors are indebted to Landmark University, PMB 1001, Omu Aran, Nigeria, for the financial assistance.

\section{References}

[1] S. Singh, "Current scenario of control of malaria," Tropical Parasitology, vol. 1, no. 2, p. 52, 2011.

[2] WHO, World Malaria Report, World Health Organization, Geneva, Switzerland, 2014.

[3] I. Budiman, R. Tjokropranoto, W. Widowati, F. Rahardja, M. Maesaroh, and N. Fauziah, "Antioxidant and anti-malarial properties of catechins," British Journal of Medicine and Medical Research, vol. 5, no. 7, pp. 895-902, 2015.

[4] P. N. Kalaria, S. C. Karad, and D. K. Raval, "A review on diverse heterocyclic compounds as the privileged scaffolds in antimalarial drug discovery," European Journal of Medicinal Chemistry, vol. 158, pp. 917-936, 2018.

[5] Y.-Q. Hu, C. Gao, S. Zhang et al., "Quinoline hybrids and their antiplasmodial and antimalarial activities," European Journal of Medicinal Chemistry, vol. 139, pp. 22-47, 2017.

[6] N. M. Anstey, N. M. Douglas, N. M. Poespoprodjo, and R. N. Price, "Plasmodium vivax," Advances in Parasitology, vol. 80, pp. 151-201, 2012.

[7] World Health Organization, Guidelines for the Treatment of Malaria, World Health Organization, Geneva, Switzerland, 3rd edition, 2015.

[8] UNICEF, Roll Back Malaria, Vol. 17, United Nations International Children's Fund, New York, NY, USA, 2000.

[9] B. N. Irungu, M. J. Mbabu, D. M. Kiboi, E. Moindi, J. Kinyua, and M. Romano, "In vivo antimalarial and acute toxicity properties of hexane and chloroform extracts from Clausena anisate (Willd.) Benth," African Journal of Pharmacology and Therapy, vol. 1, pp. 24-29, 2012.

[10] World Health Organization, World Malaria Report, World Health Organization, Geneva, Switzerland, 2018.

[11] S. Kumar, T. Bhardwaj, D. Prasad, and R. Singh, "Drug targets for resistant malaria: historic to future perspectives," Biomedicine and Pharmacotheraphy, vol. 104, pp. 8-27, 2018.

[12] O. A. Mokuolu, A. A. Adewara, S. O. Ayetoro, and E. O. Okoro, "Effect of artemisinin-based treatment policy on consumption pattern of antimalarials," The American Journal of Tropical Medicine and Hygiene, vol. 76, no. 1, pp. 7-11, 2007.

[13] J. O. Adebayo and S. O. Malomo, "The effect of co-administration of dihydroartemisinin with vitamin $\mathrm{E}$ on the activities of cation ATPases in some rat tissues," Nigerian Journal of Pure and Applied Sciences, vol. 17, pp. 1245-1252, 2002.

[14] A. C. Boareto, J. C. Muller, A. C. Bufalo et al., "Toxicity of artemisinin (Artemisia annua L.) in two different periods of pregnancy in Wistar rats," Reproductive Toxicology, vol. 25, no. 2, pp. 239-246, 2008.

[15] K. Borstnik, I.-H. Paik, T. A. Shapiro, and G. H. Posner, "Antimalarial chemotherapeutic peroxides: artemisinin, yingzhaosu A and related compounds," International Journal for Parasitology, vol. 32, no. 13, pp. 1661-1667, 2002.

[16] S. O. Oladeji, F. E. Adelowo, A. P. Oluyori, and D. T. Bankole, "Ethnobotanical description and biological activities of Senna alata," Evidence-Based Complementary and Alternative Medicine, vol. 2020, Article ID 2580259, 12 pages, 2020.

[17] O. S. Oladeji, F. E. Adelowo, D. T. Ayodele, and K. A. Odelade, "Phytochemistry and pharmacological activities of cymbopogon citratus: a review," Scientific African, vol. 6, Article ID e00137, 2019.

[18] O. S. Oladeji, K. A. Odelade, and J. K. Oloke, "Phytochemical screening and antimicrobial investigation of Moringa oleifera leaf extracts," African Journal of Science, Technology, Innovation and Development, vol. 12, no. 1, pp. 79-84, 2020.

[19] J. B. Calixto, "Twenty-five years of research on medicinal plants in Latin America: a personal view," Journal of Ethnopharmacology, vol. 100, no. 1-2, pp. 131-134, 2005.

[20] J. Bero, H. Ganfon, M.-C. Jonville et al., "In vitro antiplasmodial activity of plants used in Benin in traditional medicine to treat malaria," Journal of Ethnopharmacology, vol. 122, no. 3, pp. 439-444, 2009.

[21] M. J. Balick, E. Elizabetsky, and S. A. Laird, Medicinal Resources of the Tropical Rain Forest, Columbia University Press, New York, NY, USA, 1996.

[22] O. S. Olorunnisola, A. Adetutu, E. A. Balogun, and A. J. Afolayan, "Ethnobotanical survey of medicinal plants used in the treatment of malarial in Ogbomoso, Southwest Nigeria," Journal of Ethnopharmacology, vol. 150, no. 1, pp. 71-78, 2013.

[23] R. F. Sarquis, I. R. Sarquis, C. P. Fernandes et al., "The use of medicinal plants in the riverside community of the Mazagão river in the Brazilian amazon, Amapá, Brazil: ethnobotanical and ethnopharmacological studies," Evidence-Based Complementary and Alternative Medicine, vol. 2019, Article ID 6087509, 25 pages, 2019.

[24] M. Katemo, P. T. Mpiana, B. M. Mbala et al., "Ethnopharmacological survey of plants used against diabetes in Kisangani city (DR Congo)," Journal of Ethnopharmacology, vol. 144, no. 1, pp. 39-43, 2012.

[25] O. A. Idowu, O. T. Soniran, O. Ajana, and D. O. Aworinde, "Ethnobotanical survey of antimalarial plants used in Ogun State, Southwest Nigeria," African Journal of Pharmacy and Pharmacology, vol. 4, pp. 55-60, 2010.

[26] M. Giday, Z. Asfaw, and Z. Woldu, "Medicinal plants of the Meinit ethnic group of Ethiopia: an ethnobotanical study," Journal of Ethnopharmacology, vol. 124, no. 3, pp. 513-521, 2009.

[27] A. Ghorbani, "Studies on pharmaceutical ethnobotany in the region of Turkmen Sahra, north of Iran," Journal of Ethnopharmacology, vol. 102, no. 1, pp. 58-68, 2005.

[28] A. Braca, C. Sortino, M. Politi, I. Morelli, and J. Mendez, "Antioxidant activity of flavonoids from Licania licaniaeflora," Journal of Ethnopharmacology, vol. 79, no. 3, pp. 379-381, 2002.

[29] B. Mendes, C. M. VenTncio, M. A. Jardim, J. C. da Silva, and C. M. Venancio, "Informac,oes ftoter'apicas ecomposic, ao qu'ımica de Mikania lindleyana DC. (Asteraceae)," Revista Brasileira de Farm' acia, vol. 83, no. 1, pp. 27-29, 2002.

[30] M. G. de Carvalho, L. F. De Oliveira Cândido, P. M. Da Costa, and V. M. Rumjanek, "Chromones from Licania arianeae(Chrysobalanaceae)," Natural Product Research, vol. 19, no. 1, pp. 7-12, 2005.

[31] N. Nundkumar and J. A. O. Ojewole, "Studies on the antiplasmodial properties of some South African medicinal plants used as antimalarial remedies in Zulu folk medicine," Methods and Findings in Experimental and Clinical Pharmacology, vol. 24, no. 7, pp. 397-401, 2002.

[32] F. Benoit-Vical, A. Valentin, V. Cournac, Y. Pélissier, M. Mallié, and J. M. Bastide, "In vitroantiplasmodial activity of stem and root extracts of Nauclea latifolia S.M. (Rubiaceae)," Journal of Ethnopharmacology, vol. 61, no. 3, pp. 173-178, 1998. 
[33] G. Bidla, V. Titanji, B. Joko, G. El-Ghazali, A. Bolad, and K. Berzins, "Antiplasmodial activity of seven plants used in African folk medicine," Indian Journal Pharmacology, vol. 36, pp. 245-246, 2004.

[34] B. Adzu, J. Abbah, H. Vongtau, and K. Gamaniel, "Studies on the use of Cassia singueana in malaria ethnopharmacy," Journal of Ethnopharmacology, vol. 88, no. 2-3, pp. 261-267, 2003.

[35] J. E. Okokon, B. N. Ita, and A. E. Udokpoh, "Antiplasmodial activity of Cylicodiscus gabunensis," Journal of Ethnopharmacology, vol. 107, no. 2, pp. 175-178, 2006.

[36] F. M. Talontsi, M. Lamshöft, C. Douanla-Meli, S. F. Kouam, and M. Spiteller, "Antiplasmodial and cytotoxic dibenzofurans from preussia sp. harboured in Enantia chlorantha oliv," Fitoterapia, vol. 93, pp. 233-238, 2014.

[37] F. F. Boyom, E. M. Kemgne, R. Tepongning et al., "Antiplasmodial activity of extracts from seven medicinal plants used in malaria treatment in Cameroon," Journal of Ethnopharmacology, vol. 123, no. 3, pp. 483-488, 2009.

[38] F. Tchoumbougnang, P. H. Zollo, E. Dagne, and Y. Mekonnen, "In VivoAntimalarial activity of essential oils from Cymbopogon citratus and Ocimum gratissimumon mice infected withPlasmodium berghei," Planta Medica, vol. 71, no. 1, pp. 20-23, 2005.

[39] M. N. Shuaibu, P. A. Wuyep, T. Yanagi, K. Hirayama, T. Tanaka, and I. Kouno, "The use of microfluorometric method for activity-guided isolation of antiplasmodial compound from plant extracts," Parasitology Research, vol. 102, no. 6, pp. 1119-1127, 2008.

[40] D. V. Dapper, B. N. Aziagba, and O. O. Ebong, "Antiplasmodial effects of the aqueous extract of Phyllanthus amarus Schumach and Thonn against Plasmodium berghei in Swiss albino mice," Nigerian Journal of Physiological Science, vol. 22, no. 1-2, pp. 19-25, 2010.

[41] J. Priyanka, L. Hingorani, and K. Nilima, "Pharmacodynamic evaluation for antiplasmodial activity of Holarrhena antidysentrica (Kutaja) and Azadirachta indica (Neemb) in Plasmodium berghei infected mice model," Asian Pacific Journal of Tropical Medicine, vol. 6, no. 7, pp. 520-524, 2013.

[42] K. Murugan, C. Panneerselvam, C. Samidoss et al., "In vivo and in vitro effectiveness of Azadirachta indica-synthesized silver nanocrystals against Plasmodium berghei and Plasmodium falciparum, and their potential against malaria mosquitoes," Research in Veterinary Science, vol. 106, no. 14-22, p. 42, 2016.

[43] F. I. D. Afolayan, O. M. Adegbolagun, B. Irungu, L. Kangethe, J. Orwa, and C. I. Anumudu, "Antimalarial actions of Lawsonia inermis, Tithonia diversifolia and Chromolaena odorata in combination," Journal of Ethnopharmacology, vol. 191, pp. 188-194, 2016.

[44] O. T. Odugbemi, O. R. Akinsulire, I. E. Aibinu, and P. O. Fabeku, "Medicinal plants useful for malaria therapy in okeigbo, ondo state, southwest Nigeria," African Journal of Traditional Complementary Alternative Medicine, vol. 4, no. 2, pp. 191-198, 2008.

[45] R. K. Cimanga, G. L. Tona, G. K. Mesia et al., "Bioassay-guided isolation of antimalarial triterpenoid acids from the leaves ofMorinda lucida," Pharmaceutical Biology, vol. 44, no. 9, pp. 677-681, 2006.

[46] B. Chithambo, X. S. Noundou, and R. W. M. Krause, "Antimalarial synergy of secondary metabolites from Morinda lucida Benth," Journal of Ethnopharmacology, vol. 199, pp. 91-96, 2017.
[47] C. N. Muthaura, J. M. Keriko, C. Mutai et al., “Antiplasmodial potential of traditional antimalarial phytotherapy remedies used by the Kwale community of the Kenyan coast," Journal of Ethnopharmacology, vol. 170, pp. 148-157, 2015.

[48] E. O. Ajaiyeoba, O. O. Ogbole, O. O. Abiodun, J. S. Ashidi, P. J. Houghton, and C. W. Wright, "Cajachalcone: an antimalarial compound from Cajanus cajan Leaf extract," Journal of Parasitology Research, vol. 2013, Article ID 703781, 5 pages, 2013.

[49] K. K. Ajibesin, B. A. Ekpo, D. N. Bala, E. E. Essien, and S. A. Adesanya, "Ethnobotanical survey of akwa ibom state of Nigeria," Journal of Ethnopharmacology, vol. 115, no. 3, pp. 387-408, 2008.

[50] J. Kayode and M. A. Omotoyinbo, "Ethnobotanical utilization and conservation of chewing sticks plants species in Ekiti state Nigeria," Research Journal of Botany, vol. 4, no. 1, pp. 107-115, 2008.

[51] T. A. Tor-anyiin, R. Sha'ato, and H. O. Oluma, "Ethnobotanical survey of anti-malarial medicinal plants amongst the Tiv people of Nigeria," Journal of Herbs Spices and Medicinal Plants, vol. 10, no. 3, pp. 61-74, 2003.

[52] K. G. Ramawat and J. M. Merillon, Bioactive Molecules and Medicinal Plants, Springer, Berlin, Germany, 2008.

[53] T. P. Devasagayam, J. C. Tilak, K. K. Boloor, K. S. Sane, S. S. Ghaskadbi, and R. D. Lele, "Free radicals and antioxidants in human health: current status and future prospects," Journal of Association of Physicians in India, vol. 52, pp. 794-804, 2004.

[54] E. David-Oku, J. Obiajunwa-Otteh, G. Akuodor, and A. Essien, "Evaluation of the antimalarial potential of Icacina senegalensis juss (Icacinaceae)," Asian Pacific Journal of Tropical Medicine, vol. 7, no. 1, pp. 469-472, 2014.

[55] S. O. Okere, J. O. Sangodele, E. Ogunwole, M. D. Adams, and M. O. Shafe, "Antiplasmodial activity of aqueous leaf extract of Cymbopogon citratus against Plasmodium falciparum infected rats," American Journal of Biomedical and Life Sciences, vol. 2, no. 3, pp. 60-64, 2014.

[56] L. A. Oseni and G. M. Akwetey, "An in-vivo evaluation of antiplasmodial activity of aqueous and ethanolic leaf extracts of Azadirachta indica in Plasmodium berghei infected balb/c mice," International Journal of Pharmaceutical Science and Research, vol. 3, no. 5, pp. 1406-1410, 2012.

[57] R. I. Mojirayo, "In vivo anti-plasmodial activity and histopathological analysis of water and ethanol extracts of a polyherbal antimalarial recipe," Journal of Pharmacognosy and Phytotherapy, vol. 9, no. 6, pp. 87-100, 2017.

[58] J. M. Agbedahunsi, A. O. Adepiti, A. A. Adedini, O. Akinsomisoye, and A. Adepitan, "Antimalarial properties of Morinda lucida and Alstonia booneion sulphadoxine-pyrimethamine and Curcuma longaon quinine in mice," Journal of Herbs, Spices \& Medicinal Plants, vol. 22, no. 1, pp. 1-10, 2016.

[59] Y. Hanifah, T. Suryawati, and G. Maryatun, "The antimalarial activity of the extract of the neem leaves (Azadirachta indica, A. Juss) on Plasmodium falciparum in vitro," in Proceedings of the Annual International Conference Syiah Kuala University, vol. 1, no. 1, Banda Aceh, Indonesia, 2011.

[60] J. O. Adebayo, K. E. Adewole, and A. U. Krettli, "Cysteinestabilised peptide extract of Morinda lucida (Benth) leaf exhibits antimalarial activity and augments antioxidant defense system in P. berghei- infected mice," Journal of Ethnopharmacology, vol. 207, pp. 118-128, 2017.

[61] P. A. Ntonga, N. Baldovini, E. Mouray, L. Mambu, P. Belong, and P. Grellier, "Activity of Ocimum basilicum, Ocimum 
canum, and Cymbopogon citratus essential oils against Plasmodium falciparum and mature-stage larvae of Anopheles funestuss," Parasite, vol. 21, p. 33, 2014.

[62] M. Farahna, S. Bedri, S. Khalid, M. Idris, C. R. Pillai, and E. A. Khalil, "Anti-plasmodial effects of Azadirachta indica in experimental cerebral malaria: apoptosis of cerebellar Purkinje cells of mice as a marker," North American Journal of Medical Sciences, vol. 2, no. 11, pp. 518-525, 2010.

[63] A. C. Adebajo, S. A. Odediran, F. A. Aliyu, P. A. Nwafor, N. T. Nwoko, and U. S. Umana, "In vivo antiplasmodial potentials of the combinations of four Nigerian antimalarial plants," Molecules, vol. 19, pp. 13136-13146, 2014.

[64] I. S. Bello, T. Oduola, O. G. Adeosun, N. O. A. Omisore, G. O. Raheem, and A. A. Ademosun, "Evaluation of antimalarial activity of various fractions of Morinda lucida leaf extract and Alstonia boonei stem bark," Global Journal of Pharmacology, vol. 3, no. 3, pp. 163-165, 2009.

[65] U. M. Chukwuocha, O. Fernández-Rivera, and M. LegorretaHerrera, "Exploring the antimalarial potential of whole Cymbopogon citratus plant therapy," Journal of Ethnopharmacology, vol. 193, pp. 517-523, 2016.

[66] P. V. V. Satish, D. Santha Kumari, and K. Sunita, "Antiplasmodial efficacy of Calotropis gigantea (L.) against Plasmodium falciparum (3D7 strain) and Plasmodium berghei (ANKA)," Journal of Vector Borne Diseases, vol. 54, no. 3, pp. 215-225, 2017.

[67] D. Arome, E. Chinedu, S. Ameh, and A. Sunday, "Comparative antiplasmodial evaluation of Cymbopogon citratus extracts in Plasmodium berghei-infected mice," Journal of Current Research in Scientific Medicine, vol. 2, no. 1, pp. 29-35, 2016.

[68] O. Okpe, N. Habila, J. Ikwebe, V. A. Upev, S. R. Okoduwa, and O. T. Isaac, "Antimalarial potential of Carica papaya and Vernonia amygdalina in mice infected with Plasmodium berghe," Journal of Tropical Medicine, vol. 2016, Article ID 8738972, 6 pages, 2016.

[69] P. A. Tarkang, F. A. Okalebo, L. S. Ayong, G. A. Agbor, and A. N. Guantai, "Anti-malarial activity of a polyherbal product (Nefang) during early and established Plasmodium infection in rodent models," Malaria Journal, vol. 13, no. 1, p. 456, 2014.

[70] G. Hintsa, G. G. Sibhat, and A. Karim, "Evaluation of antimalarial activity of the leaf latex and TLC isolates from Aloe megalacantha baker in Plasmodium berghei infected mice," Evidence-Based Complementary and Alternative Medicine, vol. 2019, Article ID 6459498, 9 pages, 2019.

[71] G. Zeleke, D. Kebebe, E. Mulisa, and F. Gashe, "In vivo antimalarial activity of the solvent fractions of fruit rind and root of Carica papaya Linn (Caricaceae) against Plasmodium berghei in mice," Journal of Parasitology Research, vol. 2017, Article ID 3121050, 9 pages, 2017.

[72] A. A. Olayode, O. S. Saka, O. C. Ajayi, and M. A. Agbaje, "Activities of aqueous extracts of mangifera indica on parasitaemia level and blood profile of plasmodium berghei-infected albino mice," PharmaTutor, vol. 4, no. 4, pp. 36-42, 2016.

[73] C. I. Orabueze, D. A. Ota, and H. A. Coker, "Antimalarial potentials of Stemonocoleus micranthus harms (leguminoseae) stem bark in Plasmodium berghei infected mice," Journal of Traditional and Complementary Medicine, vol. 10, no. 1, pp. 70-78, 2019.

[74] E. I. O. Ajayi, M. A. Adeleke, T. Y. Adewumi, and A. A. Adeyemi, "Antiplasmodial activities of ethanol extracts of Euphorbia hirtawhole plant and Vernonia amygdalinaleaves in Plasmodium berghei-infected mice," Journal of Taibah University for Science, vol. 11, no. 6, pp. 831-835, 2017.

[75] G. C. Akuodor, A. G. Ahunna, E. M. Nwakaego, C. K. Chimsorom, and A. E. Chile, "Antimalarial potential of the ethanolic leaf extract of Pseudocedrala kotschyi," Journal of Acute Disease, vol. 4, no. 1, pp. 23-27, 2015.

[76] M. Gupta, U. Mazumder, P. Gomathi, and V. T. Selvan, "Antimicrobial activity of methanol extracts of Plumeria acuminata Ait," Leaves and Tephrosia Purpurea (Linn.) Pers. Roots" Natural Radiance, vol. 7, no. 2, pp. 102-105, 2008.

[77] T. Tcheghebe, N. Tatong, S. Armel, K. Justin, and N. Justin, "Ethnobotanic survey of medicinal plants used for malaria therapy in western Cameroon," Journal of Medicinal Plant Studies, vol. 4, no. 3, pp. 248-258, 2016.

[78] E. O. Agbaje and A. O. Onabanjo, "The effects of extracts of Enantia chloranthain malaria," Annals of Tropical Medicine \& Parasitology, vol. 85, no. 6, pp. 585-590, 1991.

[79] R. L. van Zyl, A. M. Viljoen, and A. K. Jäger, "In vitro activity of Aloe extracts against Plasmodium falciparum," South African Journal of Botany, vol. 68, no. 1, pp. 106-110, 2002.

[80] T. Teka, D. Bisrat, M. Yeshak, and K. Asres, "Antimalarial activity of the chemical constituents of the leaf latex of Aloe pulcherrima Gilbert and Sebsebe," Molecules, vol. 21, no. 11, p. 1415, 2016.

[81] K. Kovendan, K. Murugan, C. Panneerselvam et al., “Antimalarial activity of Carica Papaya (family: Caricaceae) leaf extract against Plasmodium Falciparum," Asian Pacific Journal of Tropical Disease, vol. 2, pp. 306-311, 2012.

[82] P. K. Deshpande, R. Gothalwal, and A. K. Pathak, "Phytochemical analysis and evaluation of antimalarial activity of Azadirachta indica," The Pharma Innovation Journal, vol. 3, no. 9, pp. 12-16, 2014.

[83] L. Lucantoni, R. S. Yerbanga, G. Lupidi, L. Pasqualini, F. Esposito, and A. Habluetzel, "Transmission blocking activity of a standardized neem (Azadirachta indica) seed extract on the rodent malaria parasite Plasmodium berghei in its vector Anopheles stephensi," Malaria Journal, vol. 9, p. 66, 2010.

[84] O. O. Kassim, M. Loyevsky, B. Elliott, A. Geall, H. Amonoo, and V. R. Gordeuk, "Effects of root extracts of Fagara zanthoxyloides on the in vitro growth and stage distribution of Plasmodium falciparum," Antimicrobial Agents and Chemotherapy, vol. 49, no. 1, pp. 264-268, 2005.

[85] R. Batista, C. C. Santana, A. V. Azevedo-Santos et al., "In vivo antimalarial extracts and constituents of Prosopis juliflora (Fabaceae)," Journal of Functional Foods, vol. 44, no. 74-78, 2018.

[86] S. MacKinnon, T. Durst, J. T. Arnason et al., "Antimalarial activity of tropical Meliaceae extracts and gedunin derivatives," Journal of Natural Products, vol. 60, no. 4, pp. 336-341, 1997.

[87] J. Bickii, N. Njifutie, J. Ayafor Foyere, L. K. Basco, and P. Ringwald, "In vitro antimalarial activity of limonoids from Khaya grandifoliola C.D.C. (Meliaceae)," Journal of Ethnopharmacology, vol. 69, no. 1, pp. 27-33, 2000.

[88] S. A. Khalid, G. M. Friedrichsen, A. Kharazmi, T. G. Theander, C. E. Olsen, and S. Brøgger Christensen, "Limonoids from Khaya senegalensis," Phytochemistry, vol. 49, no. 6, pp. 1769-1772, 1998.

[89] M. C. Joshi, K. J. Wicht, D. Taylor, R. Hunter, P. J. Smith, and T. J. Egan, "In vitro antimalarial activity, b-haematin inhibition and structure-activity relationships in a series of 
quinoline triazoles," European Journal of Medicinal Chemistry, vol. 69, 2013.

[90] S. Bertani, E. Houël, D. Stien et al., "Simalikalactone D is responsible for the antimalarial properties of an Amazonian traditional remedy made with Quassia amara L. (Simaroubaceae)," Journal of Ethnopharmacology, vol. 108, no. 1, pp. 155-157, 2006.

[91] R. Ansa-Asamoah, G. J. Kapadia, H. A. Lloyd, and E. A. Sokoloski, "Picratidine, a new indole alkaloid from Picralima nitida seeds," Journal of Natural Products, vol. 53, no. 4, pp. 975-977, 1990.

[92] O. Aldulaimi, F. I. Uche, H. Hameed et al., "A characterization of the antimalarial activity of the bark of Cylicodiscus gabunensis harms," Journal of Ethnopharmacology, vol. 198, pp. 221-225, 2017.

[93] Y. Fouokeng, H. M. Feumo Feusso, J. E. Mbosso Teinkela et al., "In vitro antimalarial, antitrypanosomal and HIV-1 integrase inhibitory activities of two Cameroonian medicinal plants: Antrocaryon klaineanum (Anacardiaceae) and Diospyros conocarpa (Ebenaceae)," South African Journal of Botany, vol. 122, pp. 510-517, 2019.

[94] M. M. Gimenez, T. A. Alvarenga, M. Groppo et al., "Antiplasmodial evaluation of Anacardium occidentale and alkylphenols," Revista Brasileira de Farmacognosia, vol. 29, no. 1, pp. 36-39, 2019.

[95] R. E. Desjardins, C. J. Canfield, J. D. Haynes, and J. D. Chulay, "Quantitative assessment of antimalarial activity in vitro by a semiautomated microdilution technique," Antimicrobial Agents and Chemotherapy, vol. 16, no. 6, pp. 710-718, 1979.

[96] W. Peters, "Drug resistance in Plasmodium berghei. I. chloroquine resistance," Experimental Parasitology, vol. 17, no. 1, pp. 80-89, 1965.

[97] R. M. K. Toghueo, E. A. M. Kemgne, P. Eke et al., "Antiplasmodial potential and GC-MS fingerprint of endophytic fungal extracts derived from Cameroonian Annona muricata," Journal of Ethnopharmacology, vol. 235, pp. 111-121, 2019.

[98] M. T. Makler and D. J. Hinrichs, "Measurement of the lactate dehydrogenase activity of Plasmodium falciparum as an assessment of parasitemia," The American Journal of Tropical Medicine and Hygiene, vol. 48, no. 2, pp. 205-210, 1993. 